\title{
Islamic Custom of Letter and Seal in Sarakata Manuscript "Surat-Surat dari Aceh"
}

\author{
Mustika Ayu Rakhadiyantia ${ }^{\text {, Priscila Fitriasih Limbong }}{ }^{\text {b }}$ \\ ${ }^{\text {a }}$ Post-Graduate Philology Department, Faculty of Humanities, University of \\ Indonesia, Depok, West Java, Indonesia \\ ${ }^{\mathrm{b}}$ Indonesian Studies Department, Faculty of Humanities, University of \\ Indonesia, Depok, West Java, Indonesia \\ mustikaayu.7293@gmail.com,priscila.fitriasih@ui.ac.id
}

\begin{abstract}
This paper presents a study on Sarakata manuscripts from the collection of the National Library of the Republic of Indonesia. The Sarakata analyzed in this research is entitled "Surat-Surat dari Aceh" with the code ML 447 written in the 19th century Jawi script. This Sarakata consists of nine letters, four of which are analyzed in this study, namely Sarakata 3, 5, 6, and 7. These Sarakatas are selected due to their historical, economic, political, social, and Islamic law aspects. The text structure is examined using 'guidance of correspondence' in Kitab Tarasul. It is found that compared to Tarasul, SSA sarakata has five elements, one of which is not contained in Kitab Tarasul, namely the pledge. The different correspondence formats are due to the fact that Aceh has its Islamic proprietary custom. Another segment under analysis was the Sarakata stamp (sikureueng seal) which the Aceh sultans used in establishing important royal letters. This seal consists of one or nine circles with different designs and decorations depicting each king's arts and specific objectives. The present study examines this usage by employing the semiosis process by Pierce. The study results indicate that the sikureueng seal, adorned with natural and geometric shapes, represented meanings such as a yearning of growth, peace, welfare, life, and longevity.
\end{abstract}

Keywords: Aceh, letter structure, sarakata, sigillography, sikureueng seal. 


\begin{abstract}
Abstrak
Artikel ini membahas naskah sarakata yang berjudul "Surat-Surat dari Aceh” koleksi Perpustakaan Nasional Republik Indonesia dengan kode ML 447. Sarakata ini ditulis pada abad ke-19 dengan aksara Jawi. Sarakata dalam SSA ML 447 terdiri atas sembilan surat, namun pada penelitian ini hanya empat sarakata yang dikaji, yakni sarakata 3, 5, 6, dan 7 karena keempat sarakata ini mengandung aspek sejarah, ekonomi, politik, sosial, dan hukum Islam. Metode yang digunakan dalam mentransliterasi adalah metode edisi kritis. Struktur teks sarakata dikaji dengan berpedoman pada Kitab Tarasul. Setelah dibandingkan, sarakata hanya memiliki 5 unsur, tetapi sarakata memiliki sebuah unsur yang tidak termasuk dalam Kitab Tarasul, yakni sumpahan. Perbedaan format berkorespondensi ini terjadi karena Aceh memiliki adatnya sendiri yang berkelindan dengan ajaran Islam. Cap dalam sarakata (cap sikureueng) juga dikaji dengan ilmu bantu sigilografi. Berdasarkan kajian sigilografi, cap sikureueng adalah 'cap yang digunakan oleh Raja Aceh dalam pembubuhan surat-surat penting kerajaan yang berisi nama sultan yang sedang memerintah'. Cap ini dapat terdiri atas sembilan lingkaran atau satu lingkaran. Desain dan hiasan cap yang berbeda-beda menggambarkan kesenian dan tujuan tertentu tiap-tiap raja. Pemaknaan ini dikaji dengan proses semiosis Pierce. Hasilnya adalah cap sikureueng dihiasi dengan bentuk-bentuk alam dan geometris, yang memiliki kandungan makna tersendiri, seperti harapan pertumbuhan, kedamaian, kesejahteraan hidup, dan kekuasaan yang panjang umur.
\end{abstract}

Kata Kunci: Aceh, struktur surat, sarakata, sigilografi, cap sikureueng

\title{
Introduction
}

Based on its genre, classic manuscripts are divided into two types: fiction and non-fiction (history). For fiction manuscripts, there are hikayat (long story), poem, and so on. Meanwhile, for non-fiction manuscripts, there are law, custom, and letter. From these types of manuscripts, letter is the one that is the least discussed. According to Gallop (1994), a letter can reveal a history of the relationship of Malay 
kings with both internal and external parties. Thousands of letter manuscripts have been stacked, waiting to be analysed.

Some letter manuscripts that were already discussed earlier, are from Aceh. Those are 1) sarakata manuscript on Jamal al-Lail Dynasty (year 1289 H/1872 CE) (Crecelius et al., 1979), 2) sarakata manuscript that contains pest tackling and food self-sufficiency (Hermansyah, 2013), and 3) the earliest sarakata from Sultanah Tajul Alam (year 1077 H/1666 CE). (Gallop, 2016)

The text of this letter manuscript that is called as sarakata becomes interesting to discuss. That is because each sarakata could potentially contains aspect of history, economy, politic, and social relations at the time that the letter/sarakata was released. Sarakata is a letter of appointment of uleebalang (Acehnese for 'hulubalang', district chief, headman, or commander) by Sultan. (Ahmad, 1972) According to Bakar, (2001), sarakata means 'a letter of appointment of a head/chief appointed by the king'. Sarakata is considered to have existed since the reign of Sultan Iskandar Muda (1607-1636).

In Indonesia, sarakata manuscripts are stored in the National Library of the Republic of Indonesia (PNRI), the National Archives of the Republic of Indonesia (ANRI), and some are kept privately by the people of Aceh. In addition, these manuscripts are also available abroad such as in Turkey, England (in digital form), and the Netherlandsi. However, the sarakata collection kept by PNRI has never been completely examined. This manuscript is the object of our research.

The Sarakata collection of PNRI consists of nine pages compiled in one bundle. Based on the text of the manuscript, this sarakata is titled 'Letters from Aceh', Surat-Surat dari Aceh 
Islamic Custom of Letter and Seal ....

(hereinafter abbreviated as SSA). SSA Sarakata contains the details of task appointed for headmen by the king, appointment of uleebalang (hulubalang), and provision from the king to keujruen (head of district). The SSA Sarakata contains a collection of letters from the Sultanate of Aceh written in 1200 Hijri or 1800 CE. (Proudfoot, 2006) The SSA Sarakata is coded ML 447 with microfilm code 665/4 Rol. It is recorded in Katalog Induk Naskah-Naskah Nusantara Koleksi Perpustakaan Nasional Republik Indonesia (Master Catalogue of the National Library of the Republic of Indonesia) collection of Malay Manuscripts, Naskah Melayu (ML). These manuscripts are not handwritten, except the ML 447 (2), which is not analysed here but has been published in Gallop (2019). Thus, the rest of the manuscripts are known as lithographic copies, that is printed reproductions of manuscripts.

Sarakata was written by a team or government secretary called keureukôn katibôi mulôk. As commonly practiced by the kings in the archipelago or 'Nusantara', the letter was written by the royal secretariat in a format that contained the elements that form a structure. Usually, a corresponding writing was arranged in a guideline called the 'Book of Correspondence', Kitab Tarasul. The elements of sarakata manuscript will be studied and compared with the book that contains the correspondence guidelines of the Malay rulers in the archipelago, the Kitab Tarasul.

In Kitab Tarasul, there are rules for writing a letter and the meaning of each part has its own rules. There is also a special team that handles the secretariat or correspondence section. Therefore, it appears that the book was used for the royal scribes, not for the general public. (Gallop, 1994) The key elements of the formal Malay letter 200 |VOL. 9 NO. 2 DECEMBER 2020 
based on Kitab Tarasul, are (1) design and decoration, (2) seal, (3) letterhead, (4) praises, (5) content, (6) provision of the sender, (7) covers and colophons, (8) address on envelopes, (9) envoy/messenger, and (10) ceremonies/customs of sending letters. (Gallop, 1994) These elements merge into a whole structure.

In SSA sarakata, a seal is affixed to the base of the manuscript. Seal or cap/stempel (Indonesian), according to Dictionary of Indonesian Language, Kamus Besar Bahasa Indonesia (Penyusun, 2016), is 'a tool for making sign (image, signature) by impressing it on paper (letters and so on); stamp; tera'. It is also called seal, from Latin sigillum 'legitimate'. "Seal-is an addition to a written document of an impression, generally in some mixture of bees-wax, form a finger-ring, or some larger surface, identifiable by the device or wording engraved on it as the property of a particular person or institution. The word 'seal' is used to describe both the impression and the tool (die or matrix) which made it.". (Zulistiasari, 2007)

Seal is used in correspondence tradition as a sign of officiality for the issued letters. Dymond (1974) asserts that seal or stamp serves as a symbol of power and legitimacy, a test of authenticity, and a proof of validity of the letter manuscript. The oldest seal in the Malay manuscript is the seal of Sultan Alaudin Riayat Syah (reigned in Aceh in 1589-1604 CE). This seal was affixed in 1602 CE. (Gallop, 1994) According to Gallop, the stamp or seal in the archipelago or 'Nusantara' is generally in the form of a circle, sometimes varying with the shape of a petal. The ingredients used were soot ink and shellac. In the seal, there is usually information about the name, date, place, and phrase/motto. ${ }^{\text {ii }}$ 
The seal found in the SSA saratakata is the Sikeureung seal used by the sultan/sultanah who ruled in Aceh. Sikureueng was a seal used by the kings of Aceh in writing important letters, such as appointment of official position, letter of authority, decree, and diplomatic agreements between nations. (Madjid, 2014) A letter written without this seal would not be considered valid. Sikeureung seal is an acculturation between Islamisation and Indianisation.

The seal consists of nine circles with different designs. This seal is called "Sikureueng seal" because in Acehnese, the word Sikureueng comes from the Acehnese language which means 'nine'. (Fakhriati, 2017) The shape of the seal is made up of one circle and some others are made up of nine circles. The shape and decoration that is different from each king illustrates the artistic characteristics of each king. The decoration in this stamp implies some meanings which will be examined using semiotics (semiosis process) by Pierce ${ }^{\mathrm{iii}}$ as part of the study of sigillography. Sigillography is the study of seal's physical aspects (Kamus Besar Bahasa Indonesia). In addition, the position of seal printing can also imply social strata between sender and recipient. In terms of content, the sikureueng seal found in the sarakata of SSA contains the names of the sultans which are arranged based on relationship closeness, both politically and genealogically, between the sultan who is enthroned with the sultans who are deceased (ancestors).

Based on the above description, it is important to study the scriptural text in SSA. At least, there are three main reasons worths an in-depth study on this. First, the SSA Sarakata has a slightly different structure from the guideline written in Kitab Tarasul. Second, the SSA Sarakata discusses political aspects in Aceh in the past, which can be 
seen from the Sikureueng seal. Third, until now there has never been an in-depth study on sarakata manuscript in SSA.

\section{Method}

Research on SSA Sarakata was carried out using a philological and sigillography approaches. Philology approach is used to study the contents of the text by applying philological research methods that are based on the text. For this reason, the text will be transliterated by the work of philology.

The philology method helps us transliterate and edit the text so that it can be understood by the readers. Meanwhile, the sigillography approach analyses the stamp in terms of its physical form, design and decoration, as well as the contents and position of the stamp which can indicate political and social strata between sender and recipient. Sigillography is a part of codicology, the study of physical aspect in the manuscript.

The method selected to present the edition of SSA sarakata manuscript and Sikureueng seal is critical edition method. This method was chosen because in the SSA sarakata, there are many words from Malay and Acehnese languages that are difficult to understand for today's general public. Therefore, additional information is given so that readers at the present time can understand. Additional information about the meaning of words or their contexts is placed in footnotes.

In translating colophons or words derived from Arabic found in the sarakata text, we were assisted by the alumnus of Universitas Islam Negeri Syarif Hidayatullah and two supervisors from the Ministry of Religious Affairs. The transliteration of the sarakata text is SSA written in Acehnese language, for example in mentioning the 
Islamic Custom of Letter and Seal ....

direction of the compass or special terms, it is guided by the Aceh Language Grammar, Kaidah Bahasa Aceh, written by Wildan, (2010).

Furthermore, in editing of the SSA Sarakata we used references from General Guide of Indonesian Spelling, Pedoman Umum Ejaan Bahasa Indonesia (PUEBI) Dictionary of Indonesian, Kamus Besar Bahasa Indonesia (KBBI). In addition, in interpreting unique words, we used Acehnese-Indonesian Dictionary, Kamus Aceh-Indonesia or Acehnese Dictionary, Kamus Basa Acèh, Arabic-Indonesian Dictionary or Kamus Arab-Indonesia (Al Munawwir), Arabic-English Dictionary or Kamus Arabic Indonesian (offline dictionary made by Kaledokus Cipta Aplikasi), Kamus Bahasa Melayu Nusantara or Malay-English Dictionary, (Wilkinson, 1901) and Dutch-Indonesian dictionary. (Moeimam et al., 2005)

After editing the text, the structure of the SSA Sarakata was then explained one by one by referring to the Book of Correspondence, Kitab Tarasul. It is a guideline used by royal secretariats in the archipelago or 'Nusantara', correspondence in ancient times. Sikureueng seal or stamp analysis was conducted using the sigillography approach. This approach is used to determine the purpose of seal printing. This research discusses the shape, size, decoration, position and meaning (with the help of Pierce's semiotics), as well as the contents of the Sikureueng seal.

\section{Result}

\section{A. Inventory and Description of the Sarakata Manuscript}

The sarakata manuscript in SSA is reserved in the National Library of the Republic of Indonesia, Perpustakaan Nasional Republik Indonesia (PNRI) and can be found in the PNRI catalogue. Based on 204 |VOL. 9 NO. 2 DECEMBER 2020 
the catalogues of Voorhove et al (1994), Iskandar (1999), Behrend (1984), Fathurahman (2010), another version of the sarakata manuscript was not found. Thus, the sarakata manuscript in SSA can be categorised as a codex unicus. There is little data on letters in the Aceh manuscript catalogues. In general, the catalogue contains religious texts and sagas. Letter manuscripts were not even specifically categorised, but included in 'others' category. The letter manuscripts contained in the catalogue are only manuscripts written by Snouck Hurgronje in Latin script. Thus, the sarakata manuscript in SSA can be categorised as a codex unicus.

In this study, the four texts found in the SSA will be discussed are manuscripts $3,5,6$, and 7 . These four manuscripts were chosen because the structure of the letter and the seal contain interesting political aspects to be further studied. The following is a description of the SSA manuscript 3, 5, 6, and 7 .

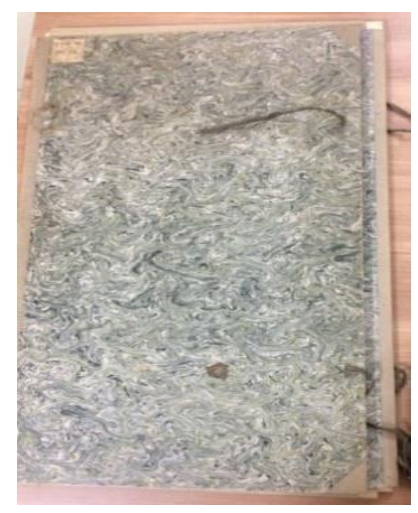

Picture 1. Cover of SSA

Manuscript Bundle. (Photo by Rakhadiyanti, 2018)

In this bundle, there are nine pages of written manuscripts, and six pages of manuscripts that only contain seals. These nine pages of written texts have content that is not related to each other. Based on the 
Islamic Custom of Letter and Seal ....

colophons, this manuscript was written around the 1200s Hijri or 1800s CE. This manuscript was written in Jawi script.
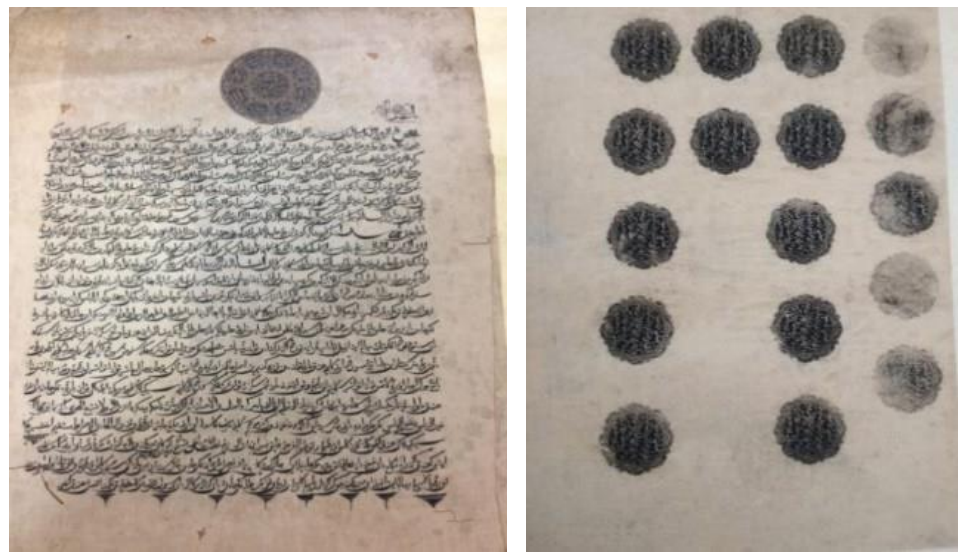

Picture 2 and 3. One of the written manuscripts and the one that only contains stamps. (Photo by Rakhadiyanti, 2018)

\section{Sarakata 3}

This script measures $54 \mathrm{~cm} \mathrm{x} 33.5 \mathrm{~cm}$. The text block is $18 \mathrm{~cm} \mathrm{x}$ $23.5 \mathrm{~cm}$. The top margin measures $12.5 \mathrm{~cm}$, the bottom border measures $23.5 \mathrm{~cm}$, the left border measures $5 \mathrm{~cm}$, and the right border measures $5 \mathrm{~cm}$.

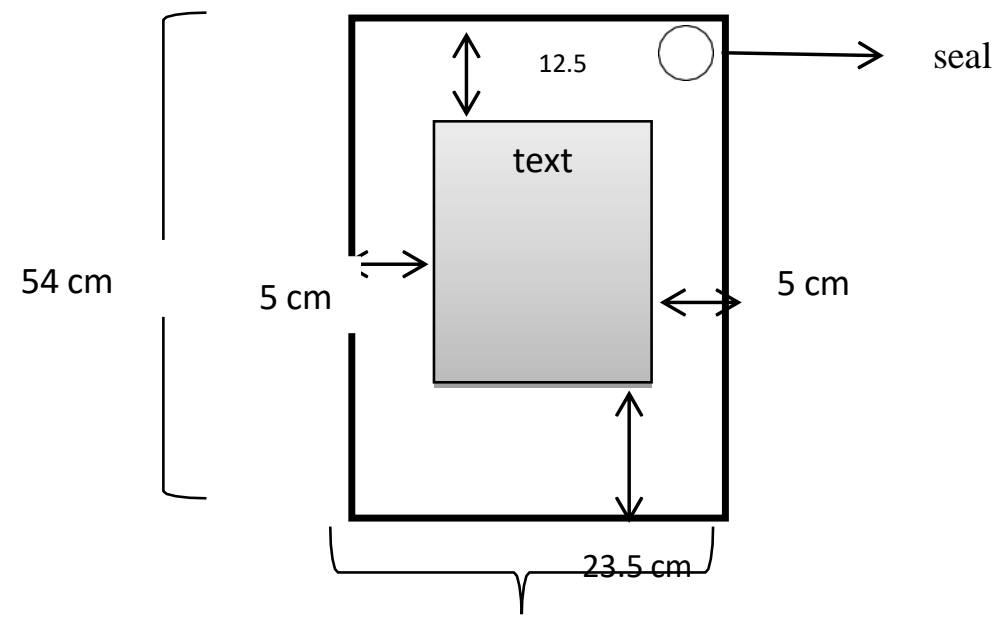

$33.5 \mathrm{~cm}$

206 |VOL. 9 NO. 2 DECEMBER 2020 
The condition of the script is still good. At the bottom of the manuscript, there is a Dutch language that reads "Afschriftgecaligrafeerd. Deze brief is het eigendom van het landschapshoofd van Idi Tjoet Oostkust van Atjeh". " Based on the colophon", this manuscript was written in 1286 Hijri or 1869 CE. The text is written in 14 lines.

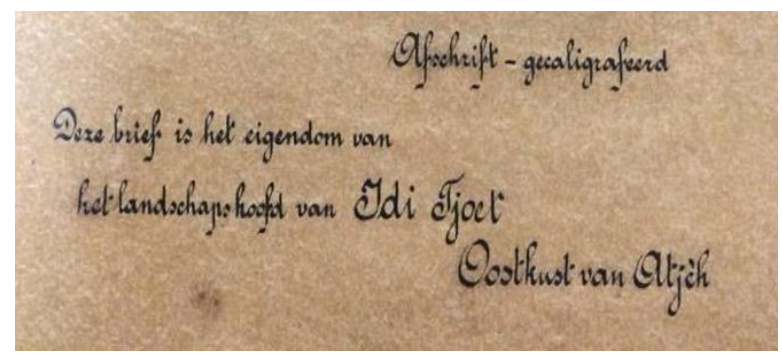

Picture 4. Dutch writing in manuscript 3. (Photo by Rakhadiyanti, 2018)

This manuscript was affixed with a faded Sikureueng seal. Although the seal ink is faded, the writing in the seal can still be read under sufficient lighting condition. The seal in this manuscript is 6.7 $\mathrm{cm}$ in diameter.

\section{Sarakata 5}

The text is written in 53 lines. Based on colophon ${ }^{\mathrm{vi}}$, this manuscript was written in $1164 \mathrm{H}$. It measures $63 \mathrm{~cm} \times 40 \mathrm{~cm}$. The text block is $50 \mathrm{~cm} \times 38 \mathrm{~cm}$. The right margin is $1.5 \mathrm{~cm}$, the left margin $0.5 \mathrm{~cm}$, the top margin is $9 \mathrm{~cm}$, and the bottom margin is $4 \mathrm{~cm}$.

The manuscript is very fragile, perforated, and torn at the bottom. Therefore, the other side iscoated in Japanese tissue. In this manuscript, there is a Sikureueng seal measuring $7.5 \mathrm{~cm}$ in diameter. The position of the seal is at the top right of the manuscript. 


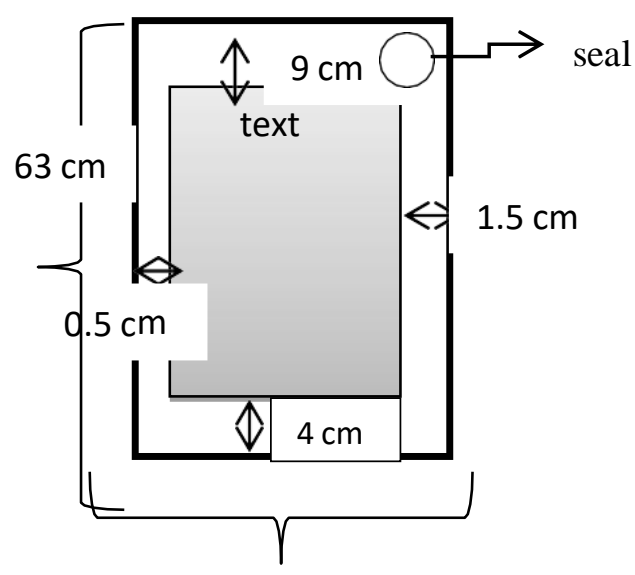

$40 \mathrm{~cm}$

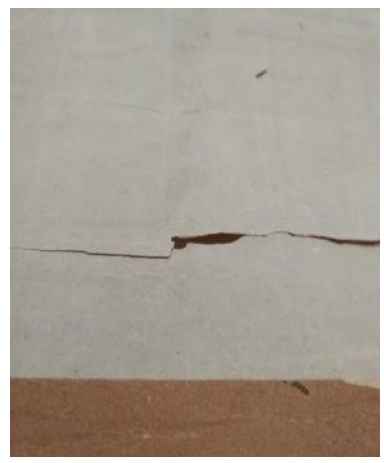

Picture 5. Rear view of the manuscript and the torn partat the bottom.

(Photo by Rakhadiyanti, 2018)

\section{Sarakata 6}

The manuscript is $60 \mathrm{~cm} \times 41.5 \mathrm{~cm}$. The text block is $33 \mathrm{~cm} \mathrm{x}$ $32.5 \mathrm{~cm}$. The upper margin is $17.5 \mathrm{~cm}$, the bottom margin is $9 \mathrm{~cm}$, the left margin is $3.5 \mathrm{~cm}$, and the right margin is $5.5 \mathrm{~cm}$. Based on the colophon $^{\text {vii, }}$ this manuscript was written in 1164 Hijri. The text is written in 53 lines.

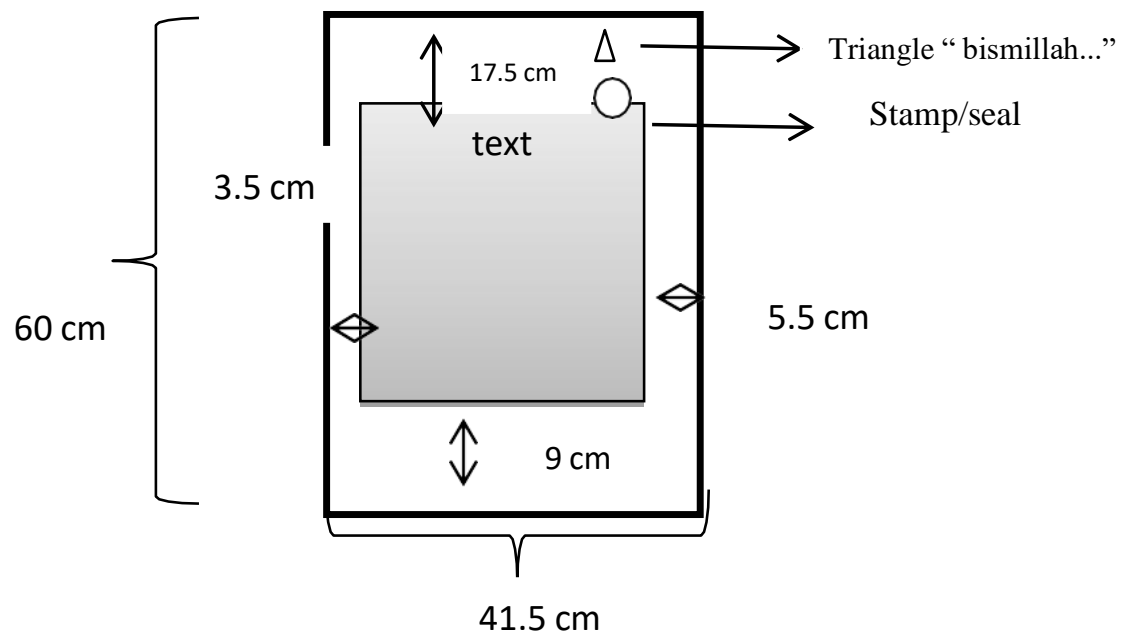


The manuscript condition is quite good, but the paper is very thin and split into two horizontally. Unlike other manuscripts, this one has letterhead that reads "bismillāh ar-rahmān ar-rahīm" ("in the name of Allah, the Most Gracious and the Most Merciful') written in calligraphy style. It is read from the outline that resembles mountains, then from the bottom line to the top line.

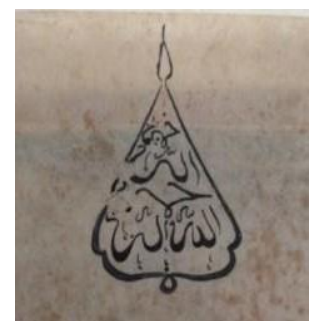

Picture 6. The letterhead reads "bismillāh ar-rahmān ar-rahīm" in manuscript 6 the upper part. (Photo by Rakhadiyanti, 2018)

In this text, a Sikureueng seal was affixed. It measures $6 \mathrm{~cm}$ in diameter. The position of the seal is above the middle text block, but slightly to the right. The distance between the triangle and the seal is $4 \mathrm{~cm}$. The text is written with a small script and very tight. At the bottom of this text, there is a Dutch language that reads "Deze sarakata is het eigendom van Keudjroen Bataoeng" viii

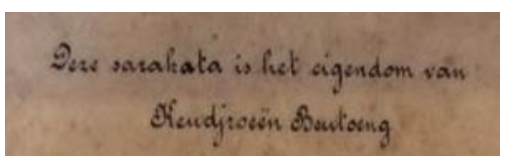

Picture 7. Dutch writing in manuscript 7. (Photo by Rakhadiyanti, 2018)

\section{Sarakata 7}

The manuscript is $40 \mathrm{~cm} \times 24 \mathrm{~cm}$. The text block is $25 \mathrm{~cm} \times 17$ $\mathrm{cm}$. The top margin is $12 \mathrm{~cm}$, the bottom margin is $3 \mathrm{~cm}$, the left margin is $2 \mathrm{~cm}$, and the right margin is $5 \mathrm{~cm}$. Based on the colophon ${ }^{\mathrm{ix}}$, this manuscript was written in 1272 Hijri. Unlike the seal in other manuscripts, this one is the only manuscript that is stamped by 
Islamic Custom of Letter and Seal ....

Sikureueng with a circle. Its diameter is $6.3 \mathrm{~cm}$. The text is written in 22 lines.

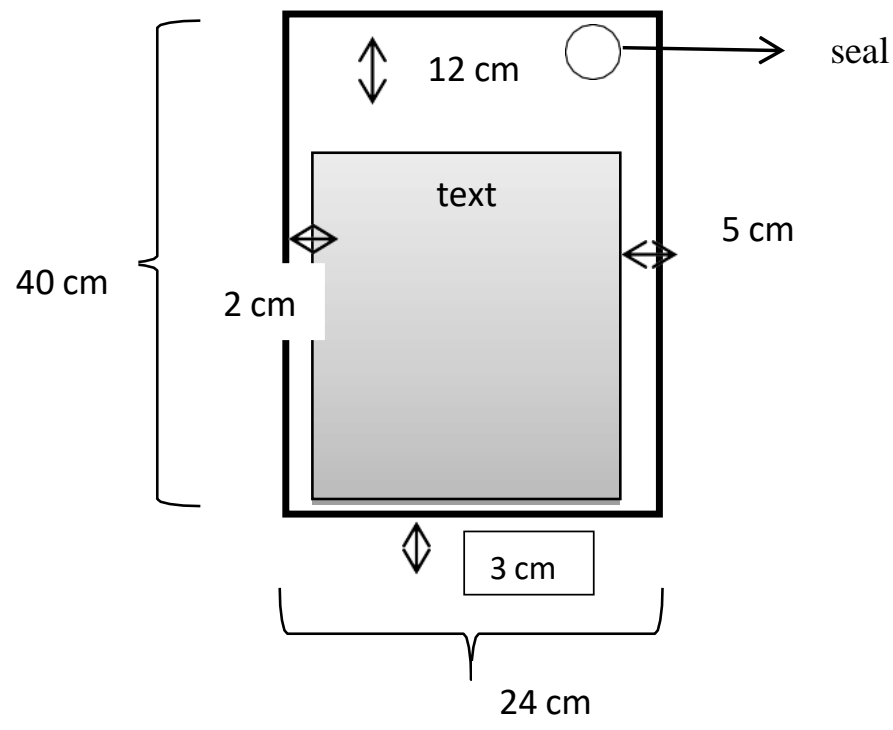

The manuscript is still good, there are no holes. However, at the bottom of the manuscript, which is the last seven lines, the ink is lost in the middle part. In this manuscript, there is also Dutch writing to the right of the text block vertically. It reads "Deze sarakata is het eigendom van Datoe $\{$ lost $\}$ ". ${ }^{x}$

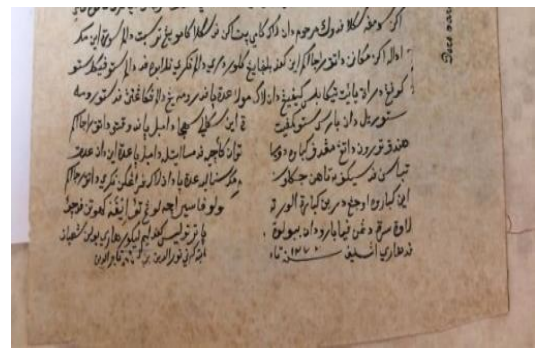

Picture 8. The bottom part of manuscript 7 That has ink lost

(Photo by Rakhadiyanti, 2018)

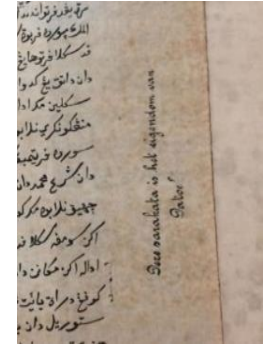

Picture 9. Dutch writing in manuscript 7.

The description above can be summarized in the table below: 
Table 1.

Basic information in Sarakata 3, 5, 6, and 7.

\begin{tabular}{|c|c|c|c|c|c|}
\hline \multirow[b]{2}{*}{$\begin{array}{l}\text { Sarakata's } \\
\text { Number }\end{array}$} & \multirow{2}{*}{$\begin{array}{c}\text { Size } \\
\text { (length } \\
\mathbf{x} \\
\text { width) }\end{array}$} & \multirow[b]{2}{*}{$\begin{array}{c}\text { Year } \\
\text { (Colophon) }\end{array}$} & \multicolumn{3}{|c|}{ Seal } \\
\hline & & & $\begin{array}{l}\text { Diameter } \\
(\varnothing) \text { Size }\end{array}$ & $\begin{array}{l}\text { Amount } \\
\text { of } \\
\text { Circles }\end{array}$ & $\begin{array}{c}\text { Name of Sultan } \\
\text { who Reigns }\end{array}$ \\
\hline Sarakata 3 & $\begin{array}{l}54 \mathrm{~cm} \mathrm{x} \\
33.5 \mathrm{~cm}\end{array}$ & $\begin{array}{c}1286 \\
\mathrm{H} / 1869 \mathrm{CE}\end{array}$ & $6.7 \mathrm{~cm}$ & 9 circles & $\begin{array}{c}\text { Paduka Sri } \\
\text { Sultan Alaudin } \\
\text { Johar Alamsyah } \\
\text { Johan Berdaulat } \\
\text { Zillullah fil Alam }\end{array}$ \\
\hline Sarakata 5 & $\begin{array}{c}63 \mathrm{~cm} \mathrm{x} \\
40 \mathrm{~cm}\end{array}$ & $\begin{array}{c}1273 \\
\mathrm{H} / 1857 \mathrm{CE}\end{array}$ & $7.5 \mathrm{~cm}$ & 9 circles & $\begin{array}{c}\text { Paduka Sri } \\
\text { Sultan Alaudin } \\
\text { Mansyur Syah } \\
\text { Johan Berdaulat } \\
\text { Zilulah Fil Alam }\end{array}$ \\
\hline Sarakata 6 & $\begin{array}{l}60 \mathrm{~cm} \mathrm{x} \\
41.5 \mathrm{~cm}\end{array}$ & $\begin{array}{c}1164 \\
\mathrm{H} / 1751 \mathrm{CE}\end{array}$ & $6 \mathrm{~cm}$ & 9 circles & $\begin{array}{c}\text { Sultan Sri } \\
\text { Alaudin Ahmad } \\
\text { Syah Johan } \\
\text { Berdaulat }\end{array}$ \\
\hline Sarakata 7 & $\begin{array}{c}40 \mathrm{~cm} \mathrm{x} \\
24 \mathrm{~cm}\end{array}$ & $\begin{array}{c}1272 \\
\mathrm{H} / 1856 \mathrm{CE}\end{array}$ & $6.3 \mathrm{~cm}$ & 1 circle & $\begin{array}{c}\text { Paduka Sri } \\
\text { Sultan Alaudin } \\
\text { Mansur Syah } \\
\text { Johan Berdaulat } \\
\text { Zillullāh Fil } \\
\text { Alam }\end{array}$ \\
\hline
\end{tabular}

\section{B. Content and Structure of Sarakata Manuscript in General}

SSA Sarakata is written in Malay. However, certain words, such as wind directions, measurements, and positions, are written in Acehnese. In the sarakata text, Arabic words are also inserted to strengthen the imperative sentences written in Malay in the previous sentence. Arabic is used to refer to a proof or dalil from the hadith or verses of the Quran. There is also an addition in Dutch language that states ownership of letter.

Each SSA Sarakata has different contents. In sarakata 3, the content is about the King who gave order to the royal secretary (called 
as keureukôn katibôi mulôk) to write a letter for a Prime Minister named Teuku Panglima Perang Nyak Bukir. In this sarakata, there are no complex political issues in its content, but in the seal. The use of this seal had been an obstacle since the reign of Sultan Mansur Syah, who used the seal of his father, Sultan Johar Alam Syah. After being analyzed from the historical perspective, it is found that during his period, the society did not give trust and loyalty as the kingdom was gradually dominated by the Netherland. (MD Azwar, 2011) So, to make this sarakata more authoritative, he used his father's seal because his father was one of the powerful kings on his era.

Further, sarakata 5 contains a decree from the king to an uleebalang (hulubalang or district chief) named Muhammad Hasyim a.k.a Penghulu Sidik Lila Digahara. Muhammad Hasyim is a son of Tengku Muallim ibn Tan Cindi ibn Po Selamat Lam Teupin, who was also an uleebalang. So, this uleebalang position was an inherited position from the father, a common practice in the past time and already mentioned in Adat Meukuta Alam. Later the rule was replaced by the decree issued by the reigning king or queen. (Hurgronje, 1996) In this sarakata, the uleebalang's taks was explained and trade taxes in Islamic law were discussed.

Sarakata 6 contains an announcement that Keujruen ${ }^{\mathrm{xi}}$ of Batang Bengkalang was dead, and then this keujruen was replaced by Keujruen of Batang Bugara Raja. In this sarakata, seven tasks in religion and social relations were also explained.

The last sarakata we analysed was sarakata 7, which contains an order from Sultan Alaudin Mansyur Syah Johan to Datuk Raja Agam to teach Islam very well to Keujruen Jeheuk in Meulaboh. This 
kind of position held by Datuk Raja Agam had existed for a long time ${ }^{\mathrm{xii}}$. Here is the quote about this type of position in sarakata 7 ,

"Maka adalah seperti Datuk Raja Agam ini dari memangnya yakni dari zaman berzaman pun ia orang menunggu negeri Meulabôh jua, bertambah lagi ia dengan titah hukum paduka marhum yang telah sudah ke kandang suruh pertimbangkan dan mengajarkan barang yang silap Keujruen Jeheuk Meulabôh akan jalan agama Allah dan syariat Muhammad dan seperti hukum yang telah ditetapkan oleh segala paduka marhum yang telah ke kandang pada Keujruen Jeuheuk Meulabôh." (Sarakata 5, baris ke-9-12).

("So, the position of Datuk Raja Agam's had existed from time when the society had lived in Meulabôh. In addition, it is the order from the kings that passed away to consider and teach about the mistakes in religious way that might be committed by Keujruen Jeheuk in Meulabôh. So he would carry out the sharia of Islam from Allah, the teaching of Prophet Muhammad as the law that had been stipulated by all of the passed kings and queens to Keujruen Jeheuk in Meulaboh. (sarakata 7, line 9-12).

As with letters in general, sarakata consists of introduction, content, and closing. The introduction in SSA sarakata begins with praise to the Prophet Muhammad and royal ancestors. There are also texts which include colophons in this section. So, in SSA sarakata, the colophon may appear at the beginning, middle or end of the text. After the praise and/or colophon, there are manuscripts that directly mention the intent and purpose (contents) and there also some that mention and explain the contents. The content of the text is about the appointment of uleebalang position by the sultan, appointment of tasks (obligations), as well as the border of the ruled areas. After the content is presented, an oath is added so that the person in charge is obliged not to violate the contents of the sarakata. If the oath is broken, the violator will get wrath from Allah and royal ancestors. The last part, closing, only exists in sarakata 5 and 6 . The following table is the format/structure of the SSA sarakata. 
Table 2.

Format/structure in Sarakata 3, 5, 6, and 7.

\begin{tabular}{clcccc}
\hline \multirow{2}{*}{ No } & \multirow{2}{*}{ Structure } & \multicolumn{5}{c}{ Sarakata } \\
\cline { 3 - 6 } & & $\mathbf{3}$ & $\mathbf{5}$ & $\mathbf{6}$ & $\mathbf{7}$ \\
\hline 1 & Letterhead & & & $\sqrt{ }$ & \\
\hline 2 & Stamp/seal & $\sqrt{ }$ & $\sqrt{ }$ & $\sqrt{ }$ & $\sqrt{ }$ \\
\hline 3 & Colophon & $\sqrt{ }$ & $\sqrt{ }$ & $\sqrt{ }$ & $\sqrt{ }$ \\
\hline 4 & Praise & $\sqrt{ }$ & $\sqrt{ }$ & $\sqrt{ }$ & $\sqrt{ }$ \\
\hline 5 & Content & $\sqrt{ }$ & $\sqrt{ }$ & $\sqrt{ }$ & $\sqrt{ }$ \\
\hline 6 & Oath & & $\sqrt{ }$ & $\sqrt{ }$ & $\sqrt{ }$ \\
\hline 7 & Closing & & $\sqrt{ }$ & $\sqrt{ }$ \\
\hline
\end{tabular}

\section{Seals in SSA Sarakata}

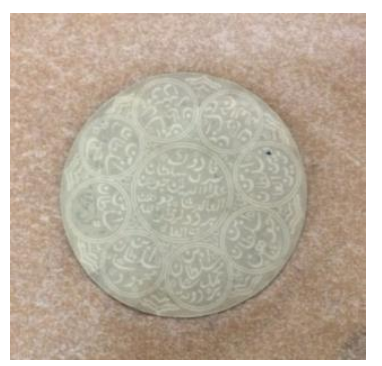

Picture 10. Sikureueng Seal in Sarakata 3. (Photo by Rakhadiyanti, 2018)

The seal in sarakata 3 has nine decorated circles, and the whole shape remains a circle. The colour of this Sikeureueng seal is more faded than the other seals. Between the largest circle and the small circle that surrounds it, there is a picture of three leaves. Meanwhile, between each small circle, the outside parts are decorated with five umbrellas (like curly brackets ' $\}$ ') arranged from short to long. This seal has a diameter of $6.7 \mathrm{~cm}$. It is affixed in SSA manuscripts which have colophon of 1286 Hijri. The largest circle in the middle reads "Paduka Sri Sultan Alaudin Johar Alamsyah Johan Berdaulat Zillullāh (f)il Alam"xiii. The circle in the clockwise direction 1 reads "ibn Sultan 214 |VOL. 9 NO. 2 DECEMBER 2020 
Tajul Alam". The circle in the clockwise direction 2 reads "ibn Sultan Zainal Abidin". The circle in the clockwise direction 4 reads "ibn Sultan Johan Syah". The circle in the clockwise direction 5 reads "ibn Sultan Muhammad Syah Berdaulat". The circle in the clockwise direction 7 reads "ibn Sultan Mahmud Syah". The circle in the clockwise direction 8 reads "ibn Sultan Ahmad Syah". The circle in the clockwise direction 10 reads "ibn Sultan Mansur Syah". The circle in the clockwise direction 11 reads "ibn Sultan Iskandar Muda"

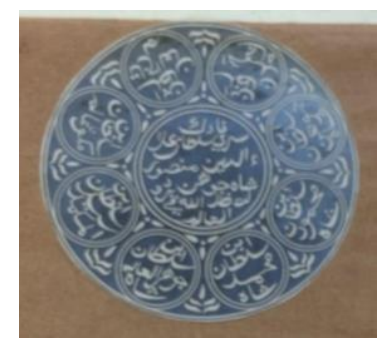

Picture 11. Sikureueng seal in Sarakata 5. (Photo by Rakhadiyanti, 2018)

The seal in sarakata 5 has nine circles with two arches (umbrellas) on the outside, and flowers with three petals (trillium flowers) between the largest circle in the centre and the small circles that surround it. Although it is decorated, the seal remains in the shape of a circle (not like a flower). This seal has a diameter of $7.5 \mathrm{~cm}$. This biggest circle in the middle reads "Paduka Sri Sultan Alaudin Mansur Syah Johan Berdaulat Zillullāh Fil Alam". xiv The circle in a clockwise direction 1 reads "ibn Sultan Ahmad Syah". The circle in a clockwise direction 2 reads "ibn Sultan Johan Syah" The circle in a clockwise direction 4 reads "ibn Sultan Mahmud Syah". The circle in a clockwise direction 5 reads "ibn Sultan Muhammad Syah". The circle in a clockwise direction 7 reads "ibn Sultan Johar Alam Syah". The circle in a clockwise direction 8 reads "Sultan Sayid Al-Mukamil". The circle 
Islamic Custom of Letter and Seal ....

in a clockwise direction 10 reads "ibn Sultan Makuta Alam". The circle in a clockwise direction 11 reads "ibn Sultan Tajul Alam".

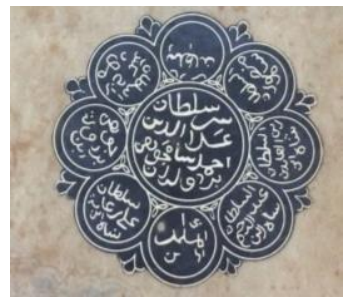

Picture 12. Sikureueng seal in Sarakata 6. (Photo by Rakhadiyanti, 2018)

The seal in sarakata 6 has nine circles with decorations, so it is shaped like a flower. There is flower decoration in the space between the large and the small circles. Outside the small circle, one with another is decorated with tulips. The seal is $6 \mathrm{~cm}$ in diameter. The biggest circle in the middle reads "Sultan Sri Alaudin Ahmad Syah Johan Berdaulat $i(b) n$ ". ${ }^{\mathrm{N}}$ The circle in a clockwise direction 2 reads "Sultan Mansur Syah (ib)n". The circle in a clockwise direction 3 reads "Sultan Zainal Abidin Syah ibn." The circle in a clockwise direction 4 reads "Sultan Abdul Rahim Syah ibn". The circle in a clockwise direction 6 reads “... Al-Malik ...n”. The circle in a clockwise direction 7 reads "Sultan Ali Riayat Syah ibn". The circle in a clockwise direction 9 reads "Johan Berdaulat ibn". The circle in a clockwise direction 11 reads "Sultan Raja (Is)kandar Muda". The circle in a clockwise direction 12 reads "Sultan".

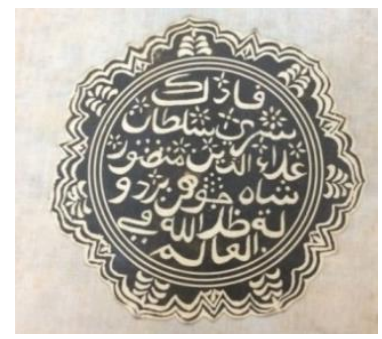

Picture 13. Sikureueng seal in Sarakata 7. (Photo by Rakhadiyanti, 2018) 216 |VOL. 9 NO. 2 DECEMBER 2020 
Unlike the other seal, the one in sarakata 7 has only one circle. This seal is decorated with an image resembling an evergreen tree outside the central circle and is closed by two layers of unbroken arches. This ornamented seal is shaped like a sunflower, its pistils are large, and its petals are small and numerous. If counted, the number of pictures of cypress trees in this seal is 7 , but between the two trees, there are three leaves. On the side-lines of the sultan's name writing, there are also decorations in the form of stars, plus sign, and images of the sun/fireworks. This seal has a diameter of $6.3 \mathrm{~cm}$. The circle in the middle reads "Paduka Sri Sultan Alaudin Mansur Syah Johan Berdaulat Zillullāh Fil Alam". ${ }^{x v i}$ This seal is affixed to the manuscript with the colophon of 1272 Hijri or 1856 CE.

\section{A Full Transliteration from One of SSA Sarakata}

This part shows a full transliteration from one of sarakatas found in the collection of Sarakata ML 447. One of this transliterated sarakata is mentioned as Sarakata 5. To be easy understanding, we write Number of Paragraph based on every main idea on the text, since this sarakata only has one page and one paragraph. Here is the full text of the transliteration.

\begin{tabular}{|c|c|c|}
\hline $\begin{array}{l}\text { Number of } \\
\text { paragraph }\end{array}$ & Malay Version & English Version \\
\hline 1 & 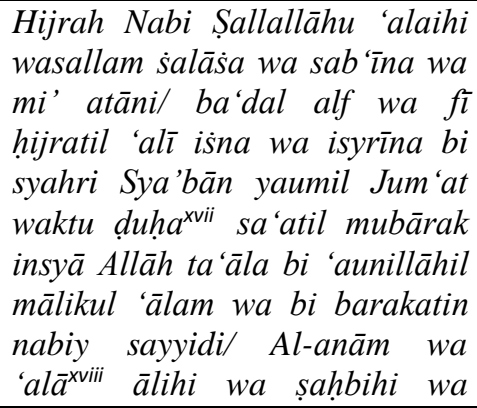 & $\begin{array}{l}\text { On the hijrah day of } \\
\text { Prophet (Muhammad) } \\
\text { Șallallāhu 'alaihi } \\
\text { wasallam salāsia wa } \\
\text { sab'ina wa mi' atāni/ } \\
\text { ba'dal alf wa fi hijratil 'alī } \\
\text { isna wa isyrīna bi syahri } \\
\text { Sya'bān yaumil Jum 'at } \\
\text { waktu duha sa'atil } \\
\text { mubārak insyā Allāh }\end{array}$ \\
\hline
\end{tabular}




\begin{tabular}{|c|c|c|}
\hline & Malay Version & English Version \\
\hline & 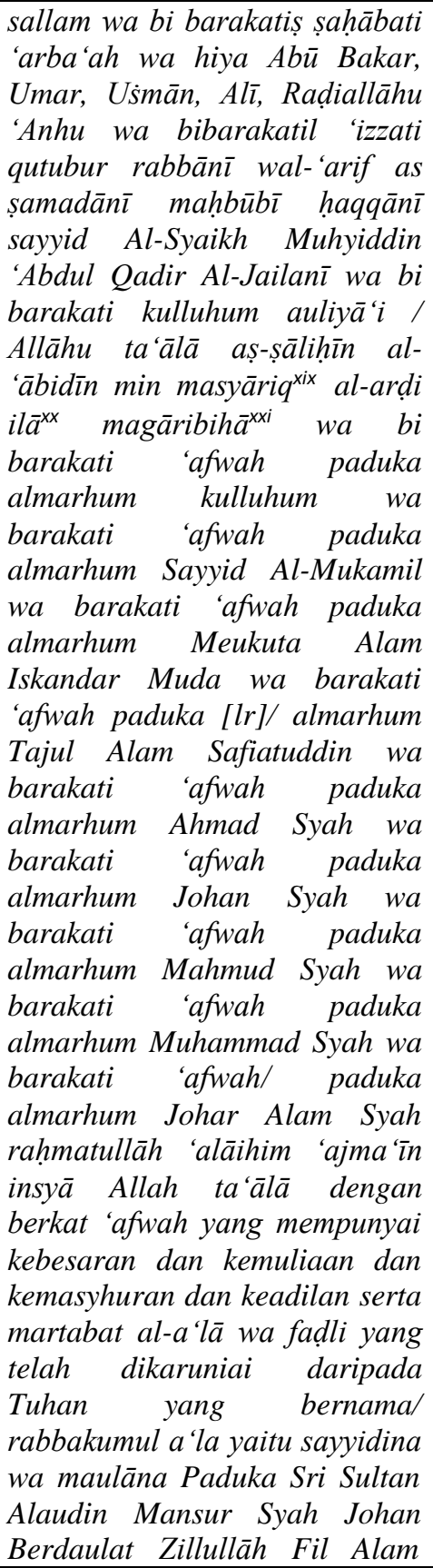 & 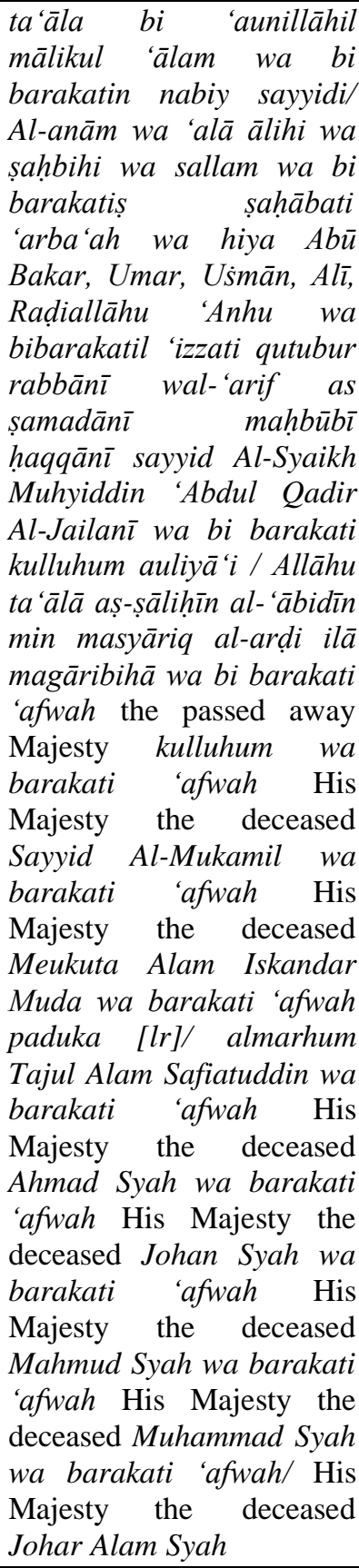 \\
\hline
\end{tabular}




\begin{tabular}{|c|c|c|}
\hline $\begin{array}{l}\text { Number of } \\
\text { paragraph }\end{array}$ & Malay Version & English Version \\
\hline & $\begin{array}{l}\text { yang kerajaan negeri Aceh } \\
\text { Ban }(\text { d)ar Darussalam. }\end{array}$ & $\begin{array}{l}\text { rahmatullāh 'alāihim } \\
\text { 'ajma'ìn insya Allah ta'āā } \\
\text { with the grace of 'afwah } \\
\text { with his greatness, glory, } \\
\text { fame, justice, and dignity } \\
\text { al-a'lā wa fadli who have } \\
\text { been gifted by God the } \\
\text { name of/ rabbakumul a'la } \\
\text { that is sayyidina wa } \\
\text { maulāna Paduka Sri } \\
\text { Sultan Alaudin Mansur } \\
\text { Syah Johan Berdaulat } \\
\text { Zillullāh Fil Alam with his } \\
\text { kingdom Aceh Ban(d)ar } \\
\text { Darussalam. }\end{array}$ \\
\hline 2 & $\begin{array}{l}\text { Tatkala baginda semayam serta } \\
\text { istirahat khair di atas } \\
\text { singga[h]sana ta[k]htal } \\
\text { kerajaan daripada emas kodrati } \\
\text { yang sepuluh mutu lagi } \\
\text { bertatahkan ratna mutu } \\
\text { manikam dan berumbaikan } \\
\text { mutiara daripada intan } \\
\text { dikarang di zabarjad }{ }^{x \times i i} \text { yang } \\
\text { telah sedia dan yang telah } \\
\text { dipertuan dalam negeri Aceh } \\
\text { Ban(d)ar Darussalam dewasa } \\
\text { itu. Maka berkabarlah/ duli } \\
\text { hadirat Syah Alam menyuruh } \\
\text { perbuat sepucuk ini terkata } \\
\text { karunia beri akan Muhammad } \\
\text { Hasyim ibn Tengku Ba Mualim } \\
\text { anak cucu penghulu yang sidik } \\
\text { sudah mati namanya Tan Cindi } \\
\text { anakPo Selamat Lam Teupin. }\end{array}$ & $\begin{array}{l}\text { When His Majesty rested } \\
\text { on his kingdom throne } \\
\text { made of gold of the highest } \\
\text { quality encrusted with } \\
\text { agate stone and tasselled } \\
\text { with pearls, diamonds and } \\
\text { gemstones that were } \\
\text { already available and } \\
\text { owned by the kingdom of } \\
\text { Aceh Ban(d)ar Darussalam } \\
\text { at the time. Then it is told } \\
\text { duli His Highness Syah } \\
\text { Alam commanded to write } \\
\text { this letter to be given to } \\
\text { Muhammad Hasyim ibn } \\
\text { Tengku Ba Mualim, the } \\
\text { descendant of a late } \\
\text { penghulu sidik named Tan } \\
\text { Cindi, the son of Po } \\
\text { Selamat Lam Teupin. }\end{array}$ \\
\hline 3 & $\begin{array}{l}\text { Syahdan adalah kepada tarikh } \\
\text { seribu dua ratus/ tujuh puluh } \\
\text { tiga tahun pada dua puluh dua } \\
\text { bulan Sya ban hari Jumat waktu } \\
\text { duha bahwa pada ketika itu } \\
\text { turun titah duli yang dipertuan } \\
\text { menjadikan Muhammad Hasyim }\end{array}$ & $\begin{array}{l}\text { Then in the year of } 1273 \text {, } \\
\text { Sya'ban month, on Friday, } \\
\text { during the duha, it is } \\
\text { commanded that duli the } \\
\text { king appointed } \\
\text { Muhammad Hasyim to be } \\
\text { a penghulu sidik, and the }\end{array}$ \\
\hline
\end{tabular}




\begin{tabular}{|c|c|c|}
\hline & Malay Version & English Version \\
\hline & 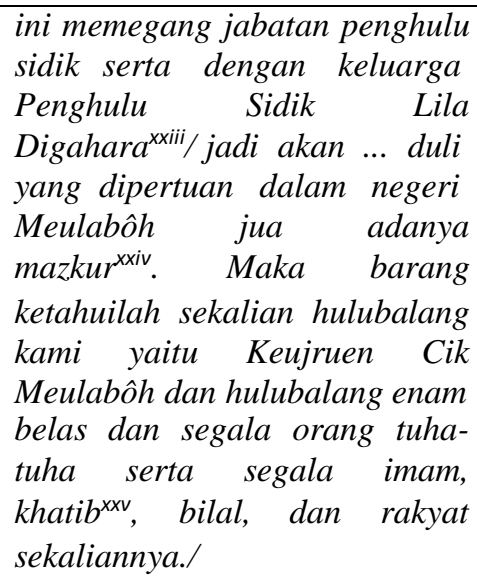 & $\begin{array}{l}\text { family of Penghulu sidik } \\
\text { Lila Digaharal to be ... } \\
\text { duli the king in Meulabôh, } \\
\text { as well as mazkur. Then it } \\
\text { is became known our } \\
\text { warriors, namely Keujruen } \\
\text { Cik Meulabôh and other } \\
\text { sixteen warriors, and all } \\
\text { old and honoured people, } \\
\text { as well as imam, khatib, } \\
\text { bilal, and the public. }\end{array}$ \\
\hline 4 & 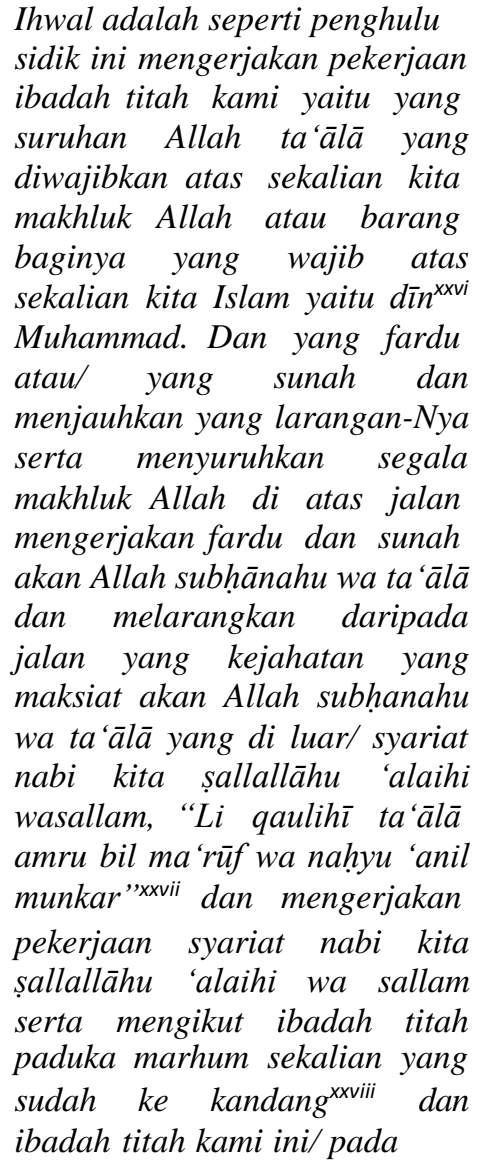 & 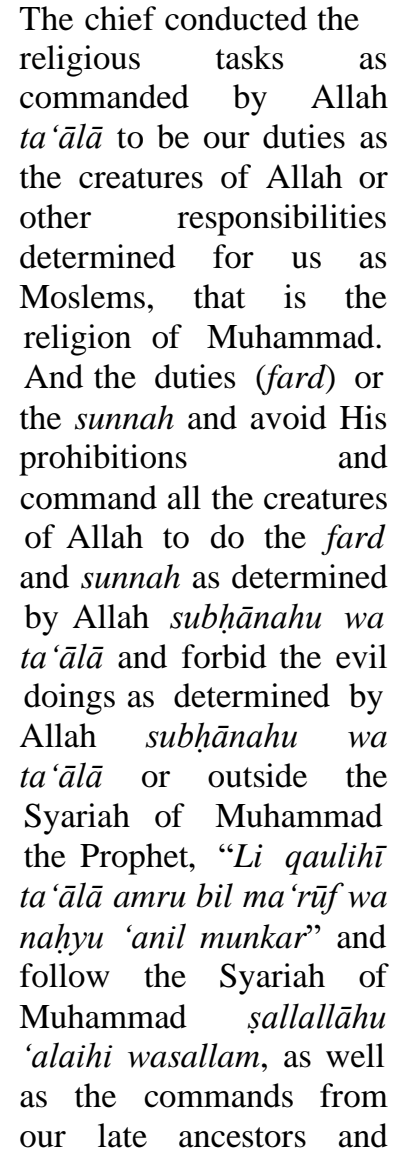 \\
\hline
\end{tabular}

220 VOL. 9 NO. 2 DECEMBER 2020 


\begin{tabular}{|c|c|c|}
\hline $\begin{array}{l}\text { Number of } \\
\text { paragraph }\end{array}$ & Malay Version & English Version \\
\hline & 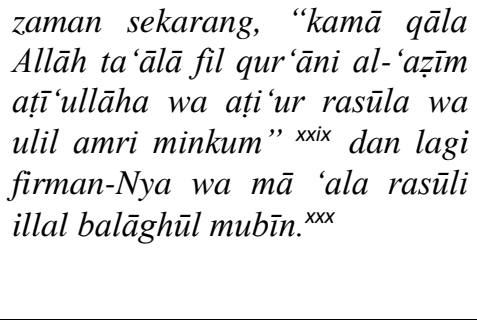 & 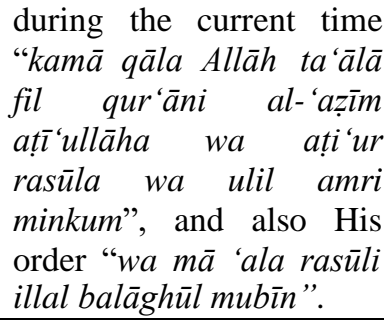 \\
\hline 5 & 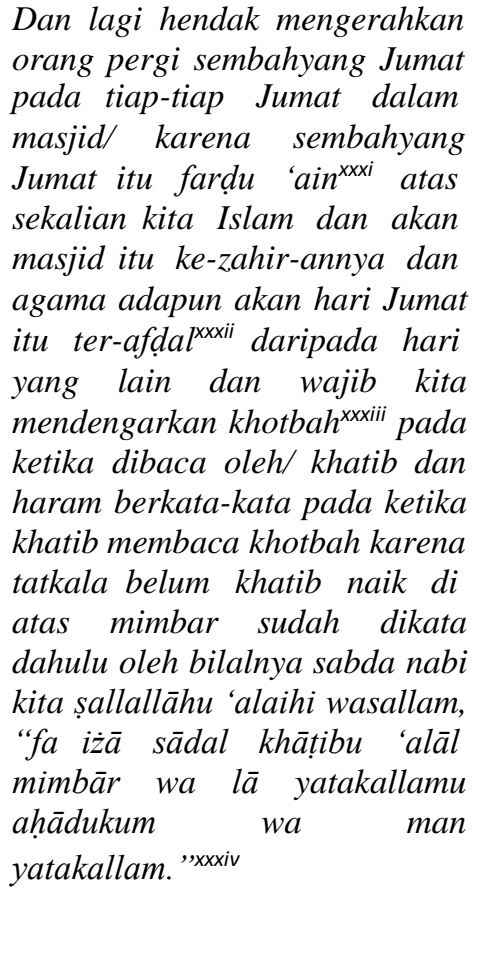 & $\begin{array}{l}\text { And also summon people } \\
\text { to have a Friday prayer } \\
\text { each Friday in the } \\
\text { mosque, as Friday prayer } \\
\text { is an obligation for us } \\
\text { Moslems and the mosque } \\
\text { is its physical matter of } \\
\text { the religion, and Friday is } \\
\text { more important than the } \\
\text { other days and it is our } \\
\text { responsibility to listen to } \\
\text { the sermon read by the } \\
\text { khatib and it is haram to } \\
\text { talk during } \\
\text { deliverance of sermon by } \\
\text { the khatib, as when the } \\
\text { khatib has not been } \\
\text { standing on the mimbar, it } \\
\text { is mentioned in the } \\
\text { command of Mohammad } \\
\text { the Prophet, "fa iża sādal } \\
\text { khātibu aläl mimbār wa } \\
\text { la yatakallamu ahāalukum } \\
\text { wa man yatakallam." }\end{array}$ \\
\hline 6 & $\begin{array}{l}\text { Dan/ lagi apabila kita kerjakan } \\
\text { yang kebajikan membuat taat } \\
\text { akan Allah ta'ālā pada hari } \\
\text { Jumat itu bertambah-tambah } \\
\text { pahala dan jikalau yang } \\
\text { kejahatan membuat maksiat } \\
\text { bertambah-tambah dosa kepada } \\
\text { Allah subhānahu wa ta'ālā } \\
\text { hendak jangan dikerjakan } \\
\text { pekerjaan yang lain pada haril } \\
\text { Jumat itu selagi belum lepas }\end{array}$ & $\begin{array}{l}\text { And even more, if we } \\
\text { conduct good deeds that } \\
\text { show our obedience to } \\
\text { Allah ta' } \bar{a} l \bar{a} \text { on Friday, } \\
\text { the merit will be } \\
\text { multiplied; and if we } \\
\text { conduct evil doings, the } \\
\text { sin towards Allah } \\
\text { subhāanahu wa ta'āla will } \\
\text { be multiplied. Do not do } \\
\text { other works on Friday }\end{array}$ \\
\hline
\end{tabular}




\begin{tabular}{|c|c|c|}
\hline $\begin{array}{l}\text { Number of } \\
\text { paragraph }\end{array}$ & Malay Version & English Version \\
\hline & 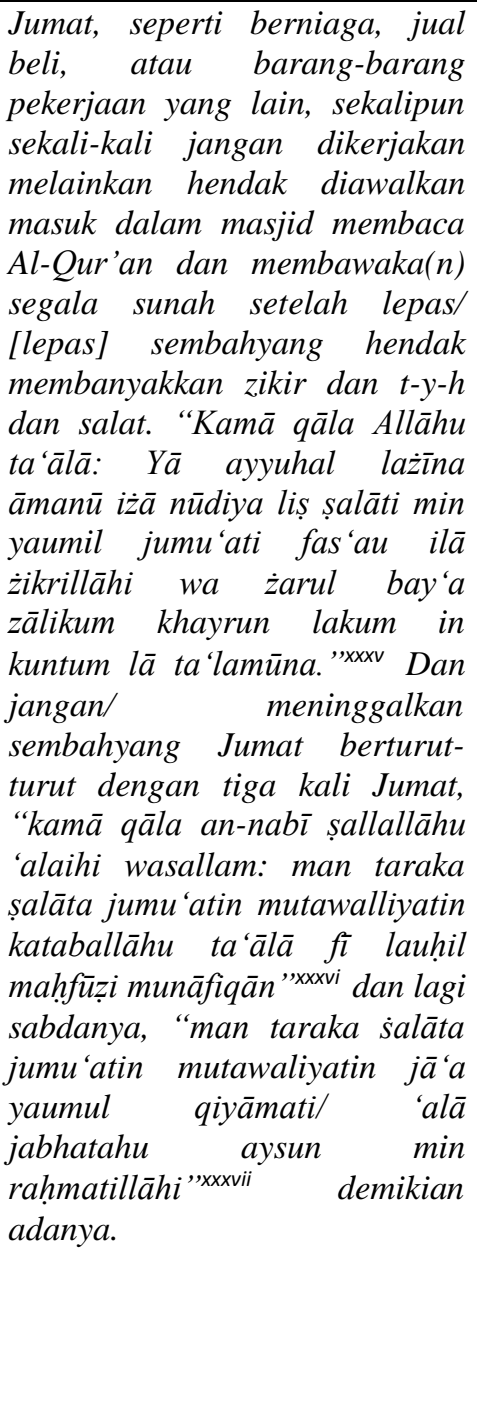 & 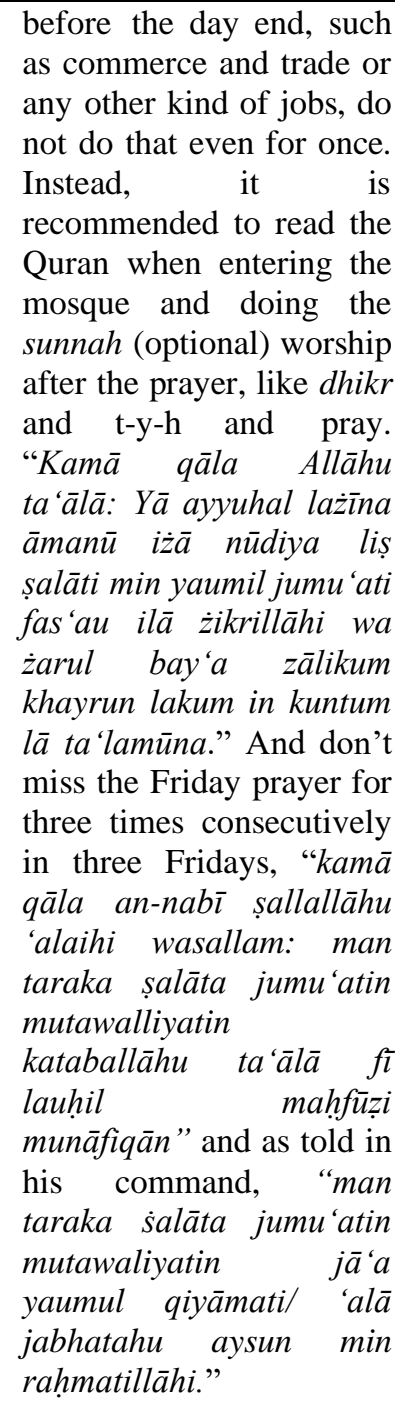 \\
\hline 7 & $\begin{array}{l}\text { Dan lagi pula apabila penghulu } \\
\text { sidik hendak mau mem(b)uatkan } \\
\text { barang-barang hukuman di atas } \\
\text { barang-barang pekerjaan kecil } \\
\text { dan besar, baik dan jahat, } \\
\text { dengan sehabis-habis } \\
\text { ijtihad }^{x \times v i i i} \text { sidik dan sesat/ } \\
\text { dengan sehabis-habis ijtihad }\end{array}$ & $\begin{array}{l}\text { And if penghulu sidik is } \\
\text { about to decide small and } \\
\text { big matters, good and evil, } \\
\text { and after the ijtihad of } \\
\text { (penghulu) sidik and a } \\
\text { moment/ following the } \\
\text { ijtihad, it is examined and } \\
\text { distinguished between the }\end{array}$ \\
\hline
\end{tabular}

222 |VOL. 9 NO. 2 DECEMBER 2020 


\begin{tabular}{|c|c|c|}
\hline $\begin{array}{l}\text { Number of } \\
\text { paragraph }\end{array}$ & Malay Version & English Version \\
\hline & 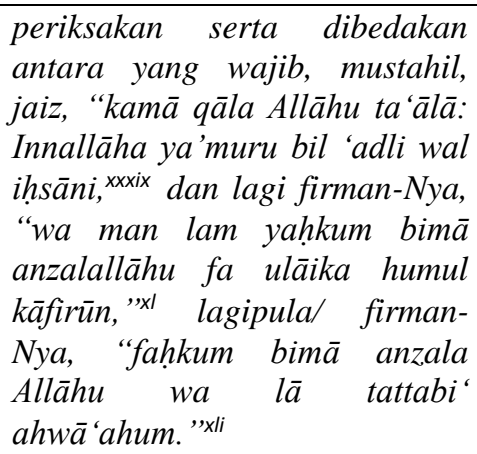 & $\begin{array}{l}\text { wajib, mustahil, jaiz, } \\
\text { "kamā qāla Allāhu ta'ālā: } \\
\text { Innallāha ya'muru bil } \\
\text { 'adli wal ihssāni, and as His } \\
\text { command, "wa man lam } \\
\text { yahkum bimā anzalallāhu, } \\
\text { fa ulāika humul kāfirūn," } \\
\text { and as His command, } \\
\text { "fahkum bima anzala } \\
\text { Allāhu wa lā tattabi" } \\
\text { ahwā'ahum." }\end{array}$ \\
\hline 8 & 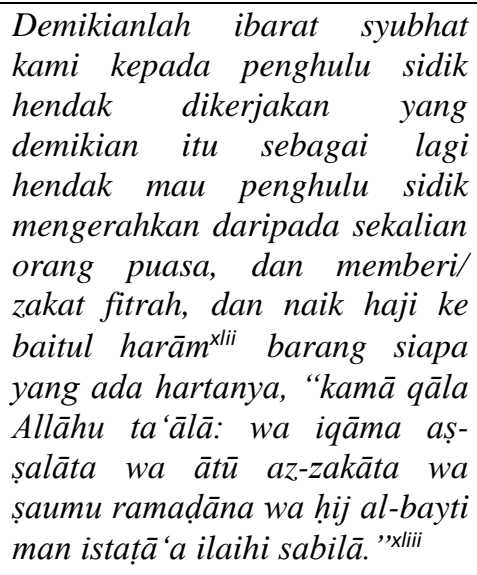 & $\begin{array}{l}\text { That is our shubha for } \\
\text { penghulu sidik to be done, } \\
\text { that is how penghulu sidik } \\
\text { is about to summon people } \\
\text { to fasting, and donate } \\
\text { zakat, and perform hajj to } \\
\text { baitul harām for those } \\
\text { with sufficient wealth, } \\
\text { "kamā qāla Allāhu ta'ālā: } \\
\text { wa iqāma aș-șalāta wa ātū } \\
\text { az-zakāta wa saumu } \\
\text { ramad̦āna wa hij al-bayti } \\
\text { man istațāa 'a ilaihi sabilā." }\end{array}$ \\
\hline 9 & $\begin{array}{l}\text { Dan lagi kami karuniakan beri } \\
\text { hukum kepada penghulu/ sidik } \\
\text { mengambil wasil }{ }^{x i v} \text { kami pada } \\
\text { tub dan perahu dan bencalang } \\
\text { selah dan barang baginya yaitu } \\
\text { daripada sekalian u sinan } \\
\text { baqa }{ }^{x / v i} \text {-nya./ Hatta orang Aceh } \\
\text { sekalipun apabila datang ia } \\
\text { sekalian yang tersebut ini mau } \\
\text { berniaga jual beli dalam negeri/ } \\
\text { Meulabôh ini yaitu sekaliannya } \\
\text { hukum penghulu sidik akan } \\
\text { mengambil wasil-nya pada } \\
\text { segala mereka yang datang } \\
\text { berniaga atau adanya. Yaitu } \\
\text { akan sekalian perkara yang }\end{array}$ & $\begin{array}{l}\text { And we inherit the law to } \\
\text { the penghulu/sidik to take } \\
\text { our wasil consists of tub } \\
\text { boat and ship and } \\
\text { bencalang selah and other } \\
\text { stuffs of his } u \text { sinan baqa. } \\
\text { Then the Acehnese, when } \\
\text { he, the one being } \\
\text { mentioned, wants to trade } \\
\text { inside the kingdom of } \\
\text { Meulabôh, the law of } \\
\text { penghulu sidik will take } \\
\text { the wasil from the traders. } \\
\text { It includes the stuff being } \\
\text { brought... and we can } \\
\text { even decide the wasil. }\end{array}$ \\
\hline
\end{tabular}




\begin{tabular}{|c|c|c|}
\hline & Malay Version & English Version \\
\hline & $\begin{array}{l}\text { dibawaka(n) barang jenis ... } \\
\text { itupun boleh kami tentukan } \\
\text { wasil-nya. }\end{array}$ & \\
\hline 10 & $\begin{array}{l}\text { Dan/ adatnya bermula jikalau } \\
\text { dibawakan dagangannya } \\
\text { daripada kain, akan wasil-nya } \\
\text { dalam seratus lima rial. Dan } \\
\text { jika dibawakannya upium dalam } \\
\text { sekatilvii, satu saku wasil-nya. } \\
\text { Dan jika gambir dijualnya } \\
\text { dalam sepuluh laksa, satu rial } \\
\text { wasil-nya. Dan jikal obat bedil } \\
\text { dalam satu tuang, satu saku } \\
\text { wasil-nya. Dan jika sekira } \\
\text { dijualnya dalam satu pikul, } \\
\text { setengah rial wasil-nya. Maka } \\
\text { sekalian perkara yang tersebut } \\
\text { ini dengan hukum duli yang } \\
\text { dipertuan Penghulu Sidik Lila } \\
\text { Digahara mengambil wasil-nya } \\
\text { sebagai lagi kami memberikan } \\
\text { titah hukum kepada penghulu } \\
\text { sidik akan sekalian perkara } \\
\text { dagangan yang keluar atau } \\
\text { yang masuk dalam negeri } \\
\text { Meulabôh, dijualnya dalam satu } \\
\text { guncaxiii satu naléh }{ }^{x l i x . ~ A d a t n y a ~} \\
\text { jikalau beras dijualnya dalam } \\
\text { satu gunca, satu rial wasil-nya. } \\
\text { Jikalau padi/ dijualnya dalam } \\
\text { satu gunca, setengah rial wasil- } \\
\text { nya. }\end{array}$ & $\begin{array}{l}\text { The custom ruled that if } \\
\text { the goods are cloth, the } \\
\text { wasil is amounted to one } \\
\text { hundred and five rial. And } \\
\text { if he brought opium in a } \\
\text { catty, the wasil is about a } \\
\text { pocket. And if gambir is } \\
\text { being sold at the rate of ten } \\
\text { laksa, the wasil is a rial. } \\
\text { And if bullets are sold in } \\
\text { one pour, the wasil is one } \\
\text { pocket. And if it is sold in } \\
\text { a picul, the wasil is a half } \\
\text { rial. Therefore, the matters } \\
\text { mentioned are ruled } \\
\text { according to the } \\
\text { regulations of duli the king } \\
\text { Penghulu sidik Lila } \\
\text { Digahara take his wasil as } \\
\text { we give the command law } \\
\text { to the penghulu sidik about } \\
\text { the matters of export and } \\
\text { import trades from and to } \\
\text { the kingdom of Meulabôh } \\
\text { is sold for a gunca a naléh. } \\
\text { The customs ruled that if } \\
\text { rice is sold in a gunca, the } \\
\text { wasil is a rial. If paddy is } \\
\text { sold in a gunca, the wasil } \\
\text { is a half rial. }\end{array}$ \\
\hline 11 & $\begin{array}{l}\text { Dan lagi pula seperti bandar } \\
\text { Meulabôh dalam hukum } \\
\text { penghulu sidik jua mengambil } \\
\text { adatnya tiada boleh barang } \\
\text { siapa masuk melainkan } \\
\text { penghulu sidik empunya } \\
\text { bahagian dengan karunia duli } \\
\text { yang dipertuan akan dial pada } \\
\text { tiap-tiap tahun kepada bulan } \\
\text { Muharram dalam satu kadi, }\end{array}$ & $\begin{array}{l}\text { And besides, the law of } \\
\text { penghulu sidik in } \\
\text { Meulabôh port also ruled } \\
\text { out that no other stuff can } \\
\text { be imported except the } \\
\text { goods owned by penghulu } \\
\text { sidik with bless duli owned } \\
\text { by him/ each Muharram } \\
\text { month in a year for a } \\
\text { caddy, four gold. Also for }\end{array}$ \\
\hline
\end{tabular}

224 |VOL. 9 NO. 2 DECEMBER 2020 


\begin{tabular}{|c|c|c|}
\hline $\begin{array}{l}\text { Number of } \\
\text { paragranh }\end{array}$ & Malay Version & English Version \\
\hline & $\begin{array}{l}\text { empat emas adatnya. Dan lagi } \\
\text { seperti rumah yang dalam } \\
\text { kampung kalau tingkat papan, } \\
\text { empat emas dalam satu tahun } \\
\text { adatnya. Jikalau orang } \\
\text { menyembelih kerbau, dada } \\
\text { kerbau itu/ penghulu sidik } \\
\text { empunya hak, demikian } \\
\text { adatnya. }\end{array}$ & $\begin{array}{l}\text { storey houses in the } \\
\text { kampong, four gold in a } \\
\text { year. If someone } \\
\text { slaughters a bull, the chest } \\
\text { of the bull is owned by } \\
\text { penghulu sidik, that is the } \\
\text { customs. }\end{array}$ \\
\hline 12 & $\begin{array}{l}\text { Dan lagi seperti adatnya } \\
\text { tumpang d-k-w perahu pada } \\
\text { orang yang jual atau orang } \\
\text { yang membeli, empat emas pada } \\
\text { orang yang menjual, empat } \\
\text { emas pada orang yang membeli, } \\
\text { demikian adatnya. Dan lagi/ } \\
\text { adat pada orang yang berkaram } \\
\text { dalam negeri Meulabôh dalam } \\
\text { satu tahun, empat emas } \\
\text { adatnya. Pada satu dapur akan } \\
\text { penghulu sidik dan lagi adat } \\
\text { pada orang yang berpukat } \\
\text { dalam segala timur, sepuluh } \\
\text { emas adatnya akan penghulu } \\
\text { sidik./ }\end{array}$ & $\begin{array}{l}\text { And also for the rules of } \\
\text { tumpeng } d-k-w \text { ship to the } \\
\text { seller or the buyer, four } \\
\text { gold for the seller, four } \\
\text { gold for the buyer, that is } \\
\text { the customs. And for } \\
\text { somebody who anchored } \\
\text { in the kingdom of } \\
\text { Meulabôh for a year, four } \\
\text { gold is the customs. In } \\
\text { one house, to penghulu } \\
\text { sidik and also the customs } \\
\text { for somebody who trawls } \\
\text { in the east, he should give } \\
\text { ten gold to penghulu } \\
\text { sidik. }\end{array}$ \\
\hline 13 & $\begin{array}{l}\text { Dan lagi tebasan padi yang } \\
\text { dalam pegangan penghulu sidik } \\
\text { dianya empunya dan lagi pada } \\
\text { orang yang pulang ke ... pada } \\
\text { seorang empat emas adatnya. } \\
\text { Dan lagi seperti orang yang } \\
\text { berdagang barang ... negeri } \\
\text { yang datang dalam negeri } \\
\text { Meulabôh, maka dengan/ } \\
\text { hukum penghulu sidik jua } \\
\text { memberi tempatnya. Dan } \\
\text { seperti negeri Pidi[m](e) itupun } \\
\text { hukum Penghulu Sidik Lila } \\
\text { Digaharajua }\end{array}$ & $\begin{array}{l}\text { And for a slash of paddy } \\
\text { on the hands of penghulu } \\
\text { sidik will be his } \\
\text { possession and for } \\
\text { somebody who comes } \\
\text { home to ... four gold. } \\
\text { And also, for somebody } \\
\text { who sell ... coming to the } \\
\text { kingdom of Meulabôh, } \\
\text { with the law of penghulu } \\
\text { sidik he will give the } \\
\text { place. And in the } \\
\text { kingdom of Pidi[m](e) the } \\
\text { law of Penghulu sidik } \\
\text { Lila Digahara also } \\
\text { applied. }\end{array}$ \\
\hline
\end{tabular}




\begin{tabular}{|c|c|c|}
\hline $\begin{array}{l}\text { Number of } \\
\text { paragraph }\end{array}$ & Malay Version & English Version \\
\hline 14 & $\begin{array}{l}\text { Dan lagi akan pulau nyiur yakni } \\
\text { pulau kelapa ataupun sudah } \\
\text { karunia duli yang dipertuan } \\
\text { akan penghulu sidik. Dan lagi } \\
\text { pula tanah/ yang jadi daripada } \\
\text { sungai dan laut penghulu sidik } \\
\text { jua mempunyai hukum. Dan lagi } \\
\text { jalur penghulu sidik bebas satu } \\
\text { dalam kawal enam belas yang } \\
\text { ke hulu hingga sampai gunung } \\
\text { gajah dan isinya sepuluh gunca. }\end{array}$ & $\begin{array}{l}\text { And also the island of } \\
\text { coconuts or the islands } \\
\text { owned by duli the king } \\
\text { penghulu sidik. Also the } \\
\text { land, river, and the sea are } \\
\text { under the law of penghulu } \\
\text { sidik. Also the route of } \\
\text { penghulu sidik is get one } \\
\text { in sixteen kawal going } \\
\text { through the upstream up to } \\
\text { the mountain of elephant } \\
\text { and the whole is amounted } \\
\text { to ten gunca. }\end{array}$ \\
\hline 15 & $\begin{array}{l}\text { Dan lagi pula wajib atas } \\
\text { Penghulu Sidik/ Lila Digahara } \\
\text { seperti anak yatim yang tiada } \\
\text { hartanya, maka wajib } \\
\text { nafkahnya atas penghulu sidik. } \\
\text { Dan akan perempuan yang } \\
\text { tiada bersuami tiada hartanya } \\
\text { itupun wajib atas penghulu sidik } \\
\text { memberikan belanjanya kadar } \\
\text { mudahnya. }\end{array}$ & $\begin{array}{l}\text { Also it is mandatory for } \\
\text { Penghulu sidik/Lila } \\
\text { Digahara, to be } \\
\text { responsible for poor } \\
\text { orphans, so their livings is } \\
\text { the responsibility of } \\
\text { penghulu sidik. And for } \\
\text { poor husbandless women } \\
\text { is also the duty of } \\
\text { penghulu sidik to make for } \\
\text { their livings. }\end{array}$ \\
\hline & $\begin{array}{l}\text { Dan akan orang \{berlubang\} } \\
\text { karam/di laut atas penghulu } \\
\text { sidik jua nafkahnya } \\
\text { sementara[n] belum mendapat } \\
\text { jalan harakatnya. Dan akan } \\
\text { orang yang berdagang mati } \\
\text { dalam bandar Meulabôh, atas } \\
\text { penghulu sidik jua menanamnya } \\
\text { jikalau ada harta peninggalan } \\
\text { orang yang mati itu di dalam } \\
\text { tangan penghulu sidik ... } \\
\text { \{rusak\} baik-baik sementara } \\
\text { belum datang walinya yang } \\
\text { patut menerima hak dan lagi } \\
\text { akan orang yang terbakar } \\
\text { rumahnya dimakan api itupun } \\
\text { wajib atas penghulu sidik } \\
\text { memberikan belanja kadar }\end{array}$ & $\begin{array}{l}\text { And for somebody who get } \\
\text { drowned in the sea is also } \\
\text { the responsibility of } \\
\text { Penghulu sidik to provide } \\
\text { for his living during his } \\
\text { search for a solution. And } \\
\text { for traders who died at the } \\
\text { port of Meulabôh, } \\
\text { penghulu sidik is also } \\
\text { responsible to bury him } \\
\text { and if there is any amount } \\
\text { of inheritance, it will be } \\
\text { kept by penghulu sidik } \\
\text { when the heirs have not } \\
\text { appeared yet, and for } \\
\text { somebody whose house } \\
\text { got burned down is also } \\
\text { the responsibility of }\end{array}$ \\
\hline
\end{tabular}




\begin{tabular}{|c|c|c|}
\hline \multirow{2}{*}{$\begin{array}{l}\text { Number of } \\
\text { paragraph }\end{array}$} & Malay Version & English Version \\
\hline & mudahnya. & $\begin{array}{l}\text { penghulu sidik to provide } \\
\text { for his living. }\end{array}$ \\
\hline & $\begin{array}{l}\text { Dan akan perangkat pegangan } \\
\text { penghulu sidik ini yang ke hulu/ } \\
\text { du... ranub dan yang ke (h)ilir } \\
\text { sampai ke (h)ulu sehingga } \\
\text { pulau kelapa dan yang ke timur } \\
\text { pasir penegak suwaq } \\
\text { gelanggang mera' yang ke } \\
\text { barat pasir air suwaq air mera' } \\
\text { demikian perangkatnya. Dan } \\
\text { lagi pun akan orang yang mati } \\
\text { yang t-h-sy-y itupun wajib atas/ } \\
\text { penghulu sidik menanamkan dia } \\
\text {.. lagi jikalau datang orang } \\
\text { membawaka(n) besi dijualnya } \\
\text { dalam bandar Meulabôh dalam } \\
\text { satu pikul, setengah rial wasil- } \\
\text { nya. Jika mulia dijualnya dalam } \\
\text { satu pikul, satu saku wasil-nya } \\
\text { penghulu sidik jua yang } \\
\text { mengembalikannya/wasil-nya. }\end{array}$ & $\begin{array}{l}\text { And for other tools the } \\
\text { penghulu sidik which go to } \\
\text { hulu/ du... ranub and from } \\
\text { downstream to upstream } \\
\text { up to the island of coconut } \\
\text { and to the east of sands } \\
\text { suwaq gelanggang mera' } \\
\text { to the west of sands suwaq } \\
\text { air mera' is the tool. Also } \\
\text { for somebody who died } t \text { - } \\
\text { h-sy-y is also the } \\
\text { responsibility of penghulu } \\
\text { sidik to bury him ... also if } \\
\text { somebody come to the port } \\
\text { of Meulabôh bringing a } \\
\text { picul of steel, the wasil is a } \\
\text { half rial. If precious stones } \\
\text { are sold in a picul, a pocket } \\
\text { of wasil is also returned by } \\
\text { penghulu sidik. }\end{array}$ \\
\hline & $\begin{array}{l}\text { Dan lagi pun waktu datang } \\
\text { kapal kami atau sekoci atau tub } \\
\text { atau sampan atau barang } \\
\text { sebagainya yang } \\
\text { membawaka(n) titah suruhan } \\
\text { kami membawaka(n) barang } \\
\text { mana negeri maka akan beras } \\
\text { maka ... breueh wajib penghulu } \\
\text { sidik memberikan/ akan orang } \\
\text { kami itu dan akan belanja yang } \\
\text { lain wajib di atas Keujruen } \\
\text { Jeuheuk Meulabôh tertanggung } \\
\text { beratnya memberikan akan } \\
\text { barang siapa yang suruhan } \\
\text { kami dan akan kayu api } \\
\text { tertanggung berat dan wajib di } \\
\text { atas Keujruen Kuala } \\
\text { memberikan akan/ orang yang } \\
\text { membawaka(n) titah kami. }\end{array}$ & $\begin{array}{l}\text { And also when our ship, } \\
\text { lifeboat, or tub boat, or } \\
\text { other stuff that brought } \\
\text { our messengers to bring } \\
\text { the goods from the } \\
\text { kingdom, including rice } \\
\ldots \text { breueh it is an } \\
\text { obligation for penghulu } \\
\text { sidik to provide a living } \\
\text { for the messenger and } \\
\text { other needs, Keujruen } \\
\text { Jeuheuk Meulabôh is } \\
\text { responsible to give our } \\
\text { messenger a wood, and is } \\
\text { heavily responsible for } \\
\text { Keujruen Kuala to give } \\
\text { the messenger who carry } \\
\text { our message. }\end{array}$ \\
\hline
\end{tabular}




\begin{tabular}{|c|c|c|}
\hline $\begin{array}{l}\text { Number of } \\
\text { paragraph }\end{array}$ & Malay Version & English Version \\
\hline & $\begin{array}{l}\text { Demikianlah kami memberikan } \\
\text { kepada Penghulu Sidik Lila } \\
\text { Digahara ini. Maka wajib atas } \\
\text { mengerjakan daripada sekalian } \\
\text { perkara seperti yang ter-mazkur } \\
\text { di dalam surat terkata ini dan } \\
\text { wajiblah sekalian hulubalang ... } \\
\text { yang/ ... tersebut ini } \\
\text { perca[ha]yakan seperti yang } \\
\text { tersebut dalam surat terkata ini } \\
\text { maka di dalam itu jika barang } \\
\text { siapa tiada dia perca[halya } \\
\text { mengubahkan seperti yang } \\
\text { tersebut dalam surat terkata ini } \\
\text { jika gh-s-y-l-h-l-y akan Allah } \\
\text { dan rasul dan kenalah/ } \\
\text { sumpahan paduka marhum } \\
\text { sekalian yang sudah ke kandang } \\
\text { kami durhakalah ia akan Allah } \\
\text { dan rasul kemudian akan kami } \\
\text { data lagi seperti dagangan } \\
\text { barang kami dan seluruh Aceh } \\
\text { dan seberang bagi yang patut di } \\
\text { dalam jual-beli orang Aceh } \\
\text { membawaka(n), makal penghulu } \\
\text { sidik mengambil wasil-nya } \\
\text { dengan hukum kami jua adanya. } \\
\text { Dan lagi jikalau orang } \\
\text { berangkat hendak menaruhkan } \\
\text { dia dan barang-barang seperti } \\
\text { kami dan yang lainnya, maka } \\
\text { wajiblah di dalam tangan } \\
\text { Penghulu Sidik Lila dikerjakan } \\
\text { penghulu sidik lpudar\} itu } \\
\text { orang di mana kami lagipun b-a } \\
\text { segalal orang berdagang } \\
\text { dengan hukum kami, "mati yang } \\
\text { bertanam hidup yang } \\
\text { memeliharakan." }\end{array}$ & $\begin{array}{l}\text { That is how we give the } \\
\text { command to Penghulu } \\
\text { sidik Lila Digahara. } \\
\text { Therefore, it is an } \\
\text { obligation to do the } \\
\text { matters as stated in this } \\
\text { letter and it is an obligation } \\
\text { for all warriors ... that/... } \\
\text { mentioned here to conduct } \\
\text { as mentioned in this letter } \\
\text { if gh-s-y-l-h-l-y of Allah } \\
\text { and Rasul and the oath of } \\
\text { His Majesty the deceased } \\
\text { is his disobedience } \\
\text { towards Allah and Rasul, } \\
\text { then we will record our } \\
\text { goods and in all over Aceh } \\
\text { and outside the region, the } \\
\text { items worthy of trading for } \\
\text { Acehnese, and penghulu } \\
\text { sidik will take the wasil } \\
\text { according to our } \\
\text { regulations. And if } \\
\text { somebody wants to place } \\
\text { himself and the goods to } \\
\text { us, it is supposed to be the } \\
\text { responsibility of Penghulu } \\
\text { sidik Lila, the duty of } \\
\text { penghulu sidik \{pudar }\} \text { in } \\
\text { which we b-a all traders } \\
\text { with our regulation, "the } \\
\text { deceased should be taken } \\
\text { care by whom alive" }\end{array}$ \\
\hline & $\begin{array}{lcr}\text { Demikian } & \text { adat dan lagi (ih)wal } \\
\text { barang } & \text { supaya } & \text { berniaga } \\
\text { \{hilang } & \text { apabila } & \text { \{pudar } \\
\text { kepada } & \text { Penghulu } & \text { Sidik Lila }\end{array}$ & $\begin{array}{l}\text { That's the customs and } \\
\text { regarding goods to be } \\
\text { traded }\{\text { lost }\} \text { if }\{\text { faded }\} \text { to } \\
\text { the Penghulu sidik Lila }\end{array}$ \\
\hline
\end{tabular}

228 |VOL. 9 NO. 2 DECEMBER 2020 


\begin{tabular}{|c|c|c|}
\hline $\begin{array}{l}\text { Number of } \\
\text { paragraph }\end{array}$ & Malay Version & English Version \\
\hline & $\begin{array}{l}\text { Digahara. Maka suruhlah } \\
\text { sepatut hanya orang itu kepada } \\
\text { Allah dan rasul/ kemudian } \\
\text { kepada Penghulu Sidik Lila } \\
\text { Digahara. Dan lagipula jikalau } \\
\text { orang bernu(m)pang kepada } \\
\text { [kepada] dan s-t-t dan Islam } \\
\text { kami atau barang ada \{pudar\} } \\
\text { sekalian binasa atau \{hilang\} la } \\
\ldots \text { sehari dua \{hilang\} bu dua } \\
\{\text { hilang\} ... penghulu sidik mau } \\
\text { usaha / akan [akan] tempatnya } \\
\text { dan jikalau ada dagangan yang } \\
\text { dibawaka(n)nya maka penghulu } \\
\text { sidik mengambil wasil-nya } \\
\text { dengan hukum kami dalam } \\
\text { seratus lima rial jua adanya. Hal } \\
\text { inilah adanya intahal kalam wa } \\
\text { katabaha Keuchik Abdul } \\
\text { Hamal. lii// }\end{array}$ & $\begin{array}{l}\text { Digahara. Therefore, order } \\
\text { them to obey God and } \\
\text { Rasull then Penghulu sidik } \\
\text { Lila Digahara. And if } \\
\text { somebody would like to } \\
\text { join in and s-t-t and Islam, } \\
\text { or the goods \{faded }\} \text { all } \\
\text { perish or }\{\text { lost }\} \text { la... two } \\
\text { for a day \{lost }\} \text { bu dua } \\
\{\text { lost }\} \text {... penghulu sidik is } \\
\text { willing to use his place and } \\
\text { if there are goods brought } \\
\text { to him, the penghulu sidik } \\
\text { will take his wasil } \\
\text { according to our regulation } \\
\text { in the amount of five rials. } \\
\text { That's the end of book } \\
\text { written by Keuchik Abdul } \\
\text { Hamal. }\end{array}$ \\
\hline
\end{tabular}

\section{Discussion}

\section{A. Analysis of the SAA Sarakata Structure}

The SSA sarakata structure has seven elements, letterhead, seal, colophon, praise, content, oath, and closing. The sarakata structure is different from that is shown in the Book of Correspondence, Kitab Tarasul, which has ten elements. In sarakata, there are no gift or provision, cover, messenger, and ceremonies or customs that are accompanying the letter. Presents/gifts or ceremonies (customs) of delivering letters are generally given or carried out when the letters are sent from a king to a king (diplomatic relations). However, because the SSA sarakata were sent from the king to uleebalang/Keujruen-in other words from superior to inferior-both of them were omitted. 
A letterhead is only found in sarakata 6. It reads "bismillāh arrahmān ar-rahìm" ("in the name of Allah, the Most Gracious and the Most Merciful'). The letterhead is above the seal or in the upper right. This position means that the sender has higher social strata than the recipient of the letter. The reason for the existence of letterhead in sarakata 6 is because this sarakata is not a regular appointment letter, but a letter of appointment that is accompanied by a royal 'ceremony' in a large hall attended by bentara (royal servants in charge of carrying royal imperial instruments) and headmen, hulubalang.

The seal in the sarakata manuscript is always in the middle of the manuscript, slightly to the right. This shows that the sender is in a higher level than the recipient. In this case, from the king to a headman, or uleebalang.

Colophons are written in Arbic and Malay. However, the writing is not always Arabic at the beginning, Malay at the end. There is also a Malay colophon written in the middle or the end of the text. In SSA Sarakata, the colophon contains the year, date, month, day, and time.

Praises almost always exist in every sarakata. This is a proof of appreciation and prayer/request for blessing to the sultans who were already deceased. In addition, praise is also given to Muslim scholars 'ulama', companions of the Prophet Muhammad, and the highest to the Prophet Muhammad PBUH. This reference indicates that Aceh not only respected the ruler or umara, but also the learned in religion or ulama.

The content of each sarakata is not much different. The contents of sarakata are, among others, about appointment of official position, boundaries of the jurisdiction, the duties in society, or the provision of land 'wakeueh' (wakaf), as well as the rules to be loyal to Islam.

230 |VOL. 9 NO. 2 DECEMBER 2020 
Oath is a promise which is written in order that what is written in the letter or sarakata is not violated. If the promise is broken, surely the person addressed in the sarakata would be condemned by Allah, and the royal deceased. Like other Malay kings' letters, the SSA sarakata also has closing. This closing words appear in sarakata 5 and 6. The closing is written with the words tammat or intahal kalam.

The Sultanate of Aceh Darussalam has its own rules in writing, especially sarakata or letter of appointment of official position by the king. This happens because Aceh is known for its staunch to Islamic teachings to the extent that the format of their letter looked very Islamic. Moreover, as (Adnan, 2013) said "From a political perspective, Aceh's kingdom official documents depicts that Islamic law has been acknowledged and implemented in all of part of life, including politics and bureaucracy." The Islamic elements seen in the sarakata are, among others, being opened with the phrase of Insha Allah which means 'God willing', followed by praise to the Prophet Muhammad, his companions, and the saints or aulia (singular wali) of Allah. In addition, Arabic is used more than the Acehnese language, and it is endorsed to be more faithful and obey Islamic law by carrying out God's commands and avoiding His prohibitions. These are reflected from Acehnese most popular proverb Hukôm ngön adat han jeuet cré, lagè zat ngön sipheuet", which means "Law and custom are inseparable, like substance and nature".

\section{B. Sigillographical Analysis}

The seal is used as the legitimacy of an issued letter, especially by the kingdom. The seal affixed in SSA Sarakata is called Sikureueng. Literally, sikureueng means 'seal nine'. This seal is formed by nine small circles that surround one of the largest circles at 
Islamic Custom of Letter and Seal ....

its centre. However, in this study, it was found that there was sikureueng seal that was not formed with nine circles. This seal is affixed in sarakata 7 . Nevertheless, the seal in sarakata 7 is still called sikureueng because based on the results of this study, sikuereueng is redefined as the seal which is affixed in important letters of the Sultanate of Aceh and functions as a sign of validity of the letter issued and it contains the name of the ruling sultan'. This is based on the data and physical aspects of the SSA sarakata that has been studied.

The Sikureueng seal was inspired by a gold coin in the Islamic period called Mohur in India. This happened because since the leadership of Sultan Iskandar Muda, kinship-like relation was established with the sultans in Delhi and South India.

The sikureueng seals affixed in the SSA sarakata in average have diameter of $6.5 \mathrm{~cm}$. The seals are generally in good condition and can be read, but there also some that are starting to fade because they are aged. The sikureueng seal is decorated with geometric images, including the tendrils, arches, leaf shapes, flowers, fences, or celestial objects.

The sikureueng seal is imprinted on the manuscript above the text block, in the middle slightly to the right. This indicates that the letter written was a social letter, because in diplomatic letters, the seal is placed under the text block. The placement between right and left also indicates the social strata between the superior and the inferior. The sikureueng seal affixed to SSA Sarakata informs that the sender is in higher position than the recipient, from the sultan to an uleebalang.

The seal is decorated with natural and geometric shapes, such as the umbrella-like arches, trillium flowers, three leaves, tulips, sunflowers, and cypresses. These signs (representamen) are icons that 232 |VOL. 9 NO. 2 DECEMBER 2020 
have their own meaning, according to context of its contents, history, or implied purpose (such as hope) in the seal.

In terms of the seal contents, the name of the ruling sultan is placed in the largest circle at the centre of the seal. Meanwhile, the small circle that surrounds it contains the names of other great sultans from the sultan's descendants or from other dynasties. In seal 5 and 7, the writing of reigning sultan matched with the colophons in the manuscript and the historical accounts. However, in seal 3 and 6, there is a discrepancy between the name of the sultan and the imprinted seal. In seal 3, the name of the reigning sultan, Sultan Alaudin Johar

Alam Syah, is imprinted. This Sultan ruled in 1802 and 1819. However, the seal was affixed to manuscript that has colophon of 1286 H. This year, if converted to CE, is 1869 . In 1869, the sultan who was governing was Sultan Mansur Syah. Sultan Alaudin Johar Alam Syah was the father of Sultan Mansur Syah. Sultan Mansur Syah used his father's seal in sarakata 3 because in 1869 , the political situation of the kingdom began to weaken with the arrival and colonisation of the Dutch. The morale of Sultan Mansur was weakened. Therefore, he applied his father's seal to support his situation. It was done because during the time of Sultan Alaudin Johar Alam Syah, the Sultanate of Aceh was respected by foreign parties, including the British. In addition, during the reign of Sultan Johar Alam Syah, internal conflicts with the higher-ups in the 'Inner' (palace) were resolved. With a seal bearing the name of the great sultans, sarakata would become more "sacred".

Something similar to seal 3 happens to seal 6 . In seal 6, the imprinted name is Sultan Ahmad Syah. However, in the colophon it is mentioned $1164 \mathrm{H}$ or if converted to $\mathrm{CE}$, it is1751. In 1751, the ruling 
sultan, Sultan Johan was the son of Sultan Ahmad. During the reign of Sultan Johan, there was a feud between the Sultan and the sagi commanders. In fact, during the era of his father, this conflict subsided. The conflict continued until the reign of his younger brother, Pocut Muhammad. Although Sultan Johan used his father's seal to make sarakata more psychologically respectable, in the end, this improper seal usage did not help much. Sultan Johan stepped down in less than a decade since the year of using his father's seal.

\section{Conclusion}

The sarakata manuscripts appear in different forms of correspondence representing Aceh with its rich customs that are interconnected with Islamic teachings. In Aceh, law and custom are inseparable, as in proverb "Hukôm ngön adat han jeuet cré, lagè zat ngön sipheuet", which means "law and custom are indivisible like substance and nature." The law mentioned in the proverb refers to Islamic law or the sharia, while adat refers to customs that is enforced in Aceh. The sikureueng seal in Sarakata symbolizes legitimacy and authenticity of letters issued by the kingdoms. Some sikureueng seals consist of nine circles - as in the literal meaning of "sikureueng" which in Acehnese means "nine", while some others consist only one circle. From the design and decoration, sikureueng seal decorated with symbols such as: umbrellas, trillium flowers, three leaves, tulips, sunflowers, and cypresses depicts the meaning of: 1) umbrella - as a protector, patron, and guide for the king and Muslims; 2) the trillium flower - as a symbol of three federation areas in Aceh which is called Lhèè Sagoë, also a three-language symbol used in sarakata; 3) three leaves - as hope for the development of the Idi Kecil area; 4) tulips - as 
a tribute to the appointment of Keujruen Batang Bugara Raja Setia Pahlawan; 5) sunflower - as a symbol for the power of Sultan Mansur Syah that lasted a long time; 6) cypress trees - as welfare and peace in religious life.

In terms of content, sikureueng seal imprints the names of the ruling sultan placed in the largest circle at the centre of the seal. Meanwhile, the small circles surrounding it represent other sultans of the sultan's descendants or from other dynasties. In terms of position, sikureueng seal was imprinted on the manuscripts above the text block, in the middle part, slightly to the right. This affixion indicates that the letter was considered a social letter. In diplomatic letters, the seal is placed under the text block. The position of the sikureueng seal affixed in the middle slightly to the right in sarakata indicates that the sender (sultan) is in a higher position than the recipient (uleebalang).

This research has limited discussion on the symbolic meaning of Acehnese Sarakata. Further studies could be undertaken in looking into sarakata content, manuscript material, or comparison with other sarakatas. Further, research could also focus on classical manuscripts focusing on the aspect of a piece of letter, political, custom, religion, and cultural values. It is hoped that the academic literature on sarakata or other Aceh letters can be richer.

\section{Acknowledgement}

We would like to extend our gratitude firstly to Prof. Dr. Titik Pudjiastuti for her support in this research. Further, many thanks to staffs at National Library of the Republic of Indonesia, Perpustakaan Nasional Republik Indonesia, who facilitated us to access the manuscript directly as well as the manuscript catalogues. Our gratitude 
Islamic Custom of Letter and Seal ....

is also to Mr. Abdullah Maulani, alumnus of Universitas Islam Negeri Syarif Hidayatullah, Ciputat, and alumnus of post-graduate philology department, University of Indonesia, for his assistance in translating Arabic language found the in the manuscript.

236 |VOL. 9 NO. 2 DECEMBER 2020 


\section{Endnotes}

i There are two codes that contains sarakata manuscript as a collection in Leiden University Library or Universiteit Bibliotheek Leiden, those are KITLV Or. 386 and Cod. Or 8244. In Or. 386, this sarakata was written from Sultan Alaudin Ibrahim Mansyur Syah and addressed to Ang Piaw (a ship's captain), also mentioned as Panglima Setia Bakti. But, this manuscript was not in a good condition since the papers sticked to each other (Iskandar, 1999; Mu'jizah, 2006; Voorhoeve et al., 1994) In Cod. Or. 8244, this sarakata are lithographed copies of sarakata, the same as held in M1. 477 (Iskandar, 1999)

${ }^{\text {ii }}$ For further information about sikureueng seal and more on Malay seals in southeast Asia, refer to Gallop who has already compiled and analysed this on her book entitled Malay Seals from The Islamic World of Southeast Asia: Content, Form Context, and Catalogue.(Gallop, 2019) There are 429 Sikureueng seals and it could be found from page 61-172.

iii In this research, I refer to Hoed (2014) which is clearer in elaborating Pierce's theory.

iv It means "Copy of manuscript. This letter belongs to Region Idi Tjoet, East Aceh."

v "Telah tersurat kepada empat belas hari bulan Muharram pada hari salasia Hijrah Nabi șallallāhu 'alaihi wasallam 1286". It means, "written on Tuesday, Muharram $14^{\text {th }} 1286$ Hijri” or Monday, April $26^{\text {th }} 1869$ CE.

vi "Hijrah Nabi Șallallāhu 'alaihi wasallam salāsa wa sab 'īna wa mi' atāni/ ba 'dal alf wa fì hijratil 'al̄ isna wa isyrīna bi syahri Sya'bān yaumil Jum 'at waktu duha sa'atil mubārak insyā Allāh ta'āla”. It means, "On Friday, Sha'ban $22^{\text {nd }} 1273$ Hijri on duha time" or Friday, April $17^{\text {th }} 1857$ CE more or less at $10.00 \mathrm{AM}$.

vii "Pada hijrah seribu seratus enam puluh empat tahun pada sepuluh hari bulan Żulhijjah vii pada yaumul sa(b)tu pada waktu zuhur". It means "on Saturday, Zulhijjah $10^{\text {th }} 1164$ Hijri" or October $30^{\text {th }} 1751 \mathrm{CE}$.

viii It means "This Sarakata belongs to Keudjroen Bataoeng." (DutchIndonesian Dictionary)

ix “Tertulis kepada lima likur hari bulan Sya'ban/ pada hari is்nain sanat 1272 ta... tabuh karunia Nuruddin bin ... Tadjuddin." It means, "written on Monday, Sha'ban $5^{\text {th }} 1272$ Hijri” or Friday, April $11^{\text {th }} 1856$ CE.

x It means "Sarakata belongs' " (Dutch-Indonesian Dictionary)

${ }^{\mathrm{xi}}$ It has the same meaning with an uleebalang 
xii To know more about the history of Datuk Raja Agam position, see. (Zainuddin, 1961)

${ }^{x i i i} \mathrm{He}$ is the father of Sultan Ibrahim Mansur Syah, the Sultan who reigned at the time this letter was released. Based on the colophon, in $1869 \mathrm{CE}$, Sultan Ibrahim Mansur Syah was the one who reigned Aceh's kingdom (1838 - 1870 $\mathrm{CE}$ ) and the name that was written in this seal was his father that already passed away. Sultan Alaudin Johar Alam Syah (r. 1802-1815) was one of the powerful kings at that time. So, in this sarakata, Sultan Ibrahim Mansur Syah borrowed his father's seal for the political and psychological purpose.

xiv As mentioned above, he was the king who reigned from 1838-1870 in Aceh's Kingdom. But in this sarakata, he no longer used his father's seal.

${ }^{\mathrm{xv}} \mathrm{He}$ is the father of Sultan Alaudin Johan Syah, the Sultan who reigned at the time this letter was released. Based on the collophon, in $1751 \mathrm{CE}$, Sultan Alaudin Johan Syah was the one who reigned Aceh's kingdom (1735-1760 $\mathrm{CE}$ ) and the name written in this seal was his deceased father's. Sultan Alaudin Ahmad Syah (r. 1726-1735 CE). King Syah was the trustable person from the Bugis aristocrats who delegated as the king on that period, despite of having an internal problem with the Dalam (court or palace) people who were Acehnese. During that troubled time, Sultan Alaudin Ahmad Syah took the throne. So, in this sarakata, Sultan Alaudin Johan Syah borrowed his father's seal to the political and psychological purpose.

xvi The same king in seal 5.

xvii The meaning is "Pada hari Jumat waktu duha, 22 Sya'ban 1273". Duha is the time when the sun is completely rising; morning before noon (around $10.00 \mathrm{am}$ ). At this time, Muslims can perform $\underline{\text { duha }}$ prayers which are sunnah (if they do it, they will get reward; but if they do not, it does not matter/does not get sin or reward). The date, if converted into the Gregorian calendar, becomes Friday, April 17, 1857, approximately 10 o'clock.

xviii In the text, it is written using ya with the dot below it (ي) which is read as 'alì. However, the meaning will be wrong and not compatible with the next word when read in this way. Therefore, transliteration would be more appropriate to write 'alā using alif maqsūrah (ى)

xix Timur (east) (Steingass, n.d.)

xx There is $\mathrm{s}$ in the text, but it is removed in transliteration; so that the meaning is correct.

${ }^{\mathrm{xxi}}$ Barat (west) (Steingass, n.d.)

xxii It is written as زبرجه in the manuscript, but it is transliterated into zabarjad because after tracing the correct word in Arabic-English Dictionary and Kamus Besar Bahasa Indonesia (Indonesia Dictionary) is not zabarjah, but 
zabarjad. According to Salim (2015), the stone, which has been mentioned in Musthalahat Al-Fiqhiyah, is the name of a precious stone. It is similar to emerald because they are both green. At the time of Islamic civilization, the stone, called the paridot stone, was once the most expensive stone during the Ottoman Caliphate in Turkey. The uses of the stone, among others, are as a decoration on rings, a decoration on a turban, and as a decoration in jewelry boxes. (Salim, 2015)

xxiii At first, Penghulu Sidik Lila Digahara was the wazir or prime minister during the reign of Sultan Mansur Syah. After being asked by the uleebalang, the leader of Sidik Lila Digahara was sent to investigate and settled all matters relating to law.(Zainuddin, 1961)

xxiv 'yang tersebut; termaktub' ('Mentioned; contained ') (Penyusun, 2016)

xxv 'Orang yang menyampaikan kotbah (pada waktu salat Jumat dsb.); juru khotbah' \{'The one who delivers the khotbah speech (during Friday prayers etc.); preacher '\} (Penyusun, 2016)

${ }^{x x v i}$ the Arabic for 'Agama' (religion) (Steingass, n.d.)

xxvii The meaning is "Because the word of Allah ta 'ālā instructs (us to do) goodness and prevent evil." (free translation)

xxviii Based on the context, this word means 'passed away to rahmatullah; die.' But, according to (Lombard, 2014), kandang is the tomb of kings in Aceh Dalam (Aceh palace) (noun). So even with the opinions (Zainuddin, 1961), kandang is 'roofed tombs' (noun).

xxix The meaning is "So the word of Allah in the Al-Qur'an: O you who have believed, obey Allah and obey the Messenger and those in authority among you." (Q.S. An-Nisā (4: 59)).

xxx The meaning is "then upon Our Messenger is only [the duty of] clear notification.” (Q.S. At-Tagābun (64: 12))

xxxi Mandatory for every Muslim (Kurniawan, 2018)

xxxii 'Better, more prime' (Penyusun, 2016)

xxxiii 'speech' (especially those that describe religious teachings) (Penyusun, 2016)

xxxiv The meaning is "When the khatib has stood on the pulpit, don't talk to someone else."

xxxv The meaning is, " $\mathrm{O}$ you who have believed, when the adhan is called for the prayer on the day of Jumuah (Friday), then proceed to the remembrance of 
Allah and leave trade. That is better for you, if you only knew." (Q.S. AlJumu'ah (62:9)

xxxvi The meaning is "Whoever leaves the Friday prayer, Allah will write on the loh mahfuz as a hypocrite." However, after tracing, there is no hadith that reads exactly like this, there is a hadith which means "Whoever leaves three times (prayer) on Friday without aging (obstruction or illness), he will be recorded as a hypocrite." (Hadith narrated by Abdurrauf Al-Munawi in Darul Kutub Al-Ilmiyah). The definition of hypocrisy in the context of this sentence according to Al-Munawi is a person who believes in Allah, but often violates religious orders. So, the hypocrites in this hadith are not hypocrites who do not believe in Allah. (Kurniawan, 2017)

xxxvii The meaning is "Whoever leaves three consecutive Friday prayers, his forehead is written as lose grace from Allah"

xxxviii "Earnest efforts which was made by religious experts to reach a verdict of sharak law regarding its settlement have not been stated in the Al-Qur'an and As-Sunnah." (Penyusun, 2016) In this context, only priest that solves the case.

xxxix The meaning is "Verily Allah commands (His creatures) to do justice and goodness."

${ }^{x 1}$ The meaning is "So the Firman of Allah ta 'ālā: Whoever does not use the law by what Allah sent on him, then they are infidel."

xli The meaning is "Use the law that Allah has sent to you (Al-Qur'an) and do not obey their lusts."

xlii Another name for Mecca

xliii The meaning is "So the Firman, Saying of Allah ta 'ālā: And establish prayers, pay zakat, fast in the month of Ramadan, and haj to the Ka'bah for anyone who can afford it."

xliv 'sesuatu hal yang datang bersamaan dengan barang lain' ('Some things that come together with other things') (Arabic-English Dictionary; MalayEnglish Dictionary)

xlv In the manuscript, it is written as بj but after being traced, it is possible that what it meant is pencalang, which is 'a large boat to carry merchandise (often used to spy on enemies using its trade characteristics)' (Penyusun, 2016).

xlvi "eternity is there"

xlvii One-third of a pound or 617 grams (Daud et al., 1999), But, in Kamus Besar Bahasa Indonesia, offline application, one pound $=500$ grams, so one 
third of a pound $=167$ grams. Looks like there was a typo on Kamus Basa Acèh.

xlviii The size, that is used for rice or beans, is equivalent to 10 naléh = approximately 200 litres (Daud et al., 1999)

xlix The size, that is used for rice or beans, is equivalent to 20 aré $=20$ bamboo/ approximately 20 litres. This word is synonymous with katéng. (Daud et al., 1999)

1 'sirih' (betel) (Bakar, 2001)

li 'beras (rice) ; nafkah hidup (basic necessities of life e.g. money, food)' (Bakar, 2001)

lii The meaning is "This paper is finished and written by Khatib Keuchik Abdul Hamal." (free translation). However, in our opinion, the name Jamal is more often found in Acehnese society than Hamal.

\section{References}

Adnan, G. (2013). Islamic and Customary Law in Aceh Darussalam Constitution. Heritage of Nusantara International Journal of Religious Literature and Heritage, 2, 145-176.

Ahmad, Z. (1972). Sekitar Kerajaan Atjeh dalam Tahun 1520 -1675. Monora.

Bakar, A. (2001). Kamus Aceh-Indonesia. Balai Pustaka.

Behrend, T.E. (1998). Katalog Induk Naskah-Naskah Nusantara

Koleksi Perpustakaan Nasional RI. Jakarta: Yayasan Obor.

Crecelius, Daniel, \& Beardow, E. A. (1979). A reputed Acehnese Sarakata of The Jamal al-Lail Dynasty. Journal of the Malaysian Branch of the Royal Asiatic Society, 51-66.

Daud, Bukhari, \& Durie, M. (1999). Kamus Basa Acèh (AcehneseIndonesian-English Thesaurus). Pasific Linguistics.

Dymond, D. P. (1974). Archaelogy and History: A Plea for Reconciliation. Thames and Hudson.

Fakhriati. (2017). Identitas Naskah Aceh dalam Aksara dan Bahasa. In Kramadibrata. 
Fathurahman, Oman, dkk. (2007). Katalog Naskah Ali Hasjmy Aceh. Tokyo: C-Dats Tokyo University of Foreign Studies, PPIM UIN Jakarta, dan Manassa.

Fathurahman, Oman. (2010). Katalog Naskah Dayah Tanoh Abee. Jakarta: Komunitas Bambu.

Gallop, A. T. (1994). The Legacy of The Malay Letter. British Library.

Gallop, A. T. (2016). Sultanah Tajul Alam's Tarakata of 1666: The Earliest Known Original Royal Decree from Aceh. In M. H. Amirudin, K. Bustaman-Ahmad, \& Baiquni (Eds.), Yusny Saby Sang Motivator: Menelusuri Karakter Pemimpin Jujur dan Ikhlas dalam Membangun Umat (pp. 312-325). Lembaga Studi Agama dan Masyarakat Aceh.

Gallop, A. T. (2019). Malay Seals from The Islamic World of Southeast Asia. NUS Press.

Hermansyah. (2013). Swasembada Pangan dan Penanggulangan Hama di Aceh Periode Kesultanan. In Prosiding Seminar Naskah Kuna Nusantara: Pangan dalam Naskah Kuna Nusantara (pp. 2-14). Perpustakaan Nasional Republik Indonesia.

Hoed, B. H. (2014). Semiotik \& Dinamika Sosial Budaya. Komunitas Bambu.

Hurgronje, S. (1996). Aceh: Rakyat dan Adat Istiadatnya. INIS. Iskandar, T. (1999). Catalogue of Malay, Minangkabau, and South Sumatran Manuscripts in The Netherlands. Documentatie Bureau Islam-Christandom.

Kurniawan, A. (2017). Tinggalkan Tiga Kali Jumat Jadi Kafir? http://nu.or.id/post/read/77260/tinggalkan-tiga-kali-jumat-jadikafir d

Kurniawan, A. (2018). Ini Jenis-Jenis Wajib dalam Hukum Islam. http://nu.or.id/post/read/86154/ini-jenis-jenis-wajib-dalamhukum-islam

Lombard, D. (2014). Kesultanan Aceh Zaman Kesultanan Iskandar Muda (1607-1636). EFEO.

Madjid, M. D. (2014). Catatan Pinggir Sejarah Aceh: Perdagangan, 242 |VOL. 9 NO. 2 DECEMBER 2020 
Diplomasi, dan Perjuangan Rakyat. Obor.

MD Azwar, P. H. (2011). Silsilah Raja-Raja Islam di Aceh. Yayasan Tun Sri Lanang.

Moeimam, Susi, \& Dkk. (2005). Kamus Belanda-Indonesia. Gramedia.

Mu'jizah. (2006). Surat Melayu Beriluminasi Raja Nusantara dan Pemerintah Hindia-Belanda Abad XVIII-XIX: Tinjauan Bentuk, Isi, dan Makna Simbolik.

Penyusun, T. (2016). Kamus Besar Bahasa Indonesia (V). Badan

Pengembangan dan Pembinaan Bahasa, Kementerian

Pendidikan dan Kebudayaan Republik Indonesia.

Proudfoot, I. (2006). Old Muslim Calendars of Southeast Asia. Brill.

Salim. (2015). 8 Varian Batu Mulia yang Dibahas dalam Kitab Klasik. Retrieved at https://hidayatullah.com/spesial/ragam/ $\mathrm{read} / 2015 / 02 / 04 / 38114 /$ ini-dia-8-\%0Avarian-batu-mulia-yangdibahas-dalam-kitab-klasik.html

Steingass, F. (n.d.). Arabic-English Dictionary. Crosby Lockwood \& Son.

Voorhoeve, Iskandar, T., \& Durie, M. (1994). Catalog of Acehnese Manuscript. Leiden University Library.

Wildan. (2010). Kaidah Bahasa Aceh. Geuci.

Wilkinson, R. . (1901). A Malay-English Dictionary. Kelly \& Walsh Ltd.

Zainuddin. (1961). Tarich Atjeh dan Nusantara. Pustaka Iskandar Muda.

Zulistiasari, N. R. (2007). Meterai-meterai pada Masa Kesultanan Ternate Akhir Abad 17-19. Universitas Indonesia. 